NBER WORKING PAPER SERIES

\title{
DO INTERACTIONS WITH CANDIDATES INCREASE VOTER SUPPORT AND PARTICIPATION? EXPERIMENTAL EVIDENCE FROM ITALY
}

\author{
Enrico Cantoni \\ Vincent Pons \\ Working Paper 27433 \\ http://www.nber.org/papers/w27433
NATIONAL BUREAU OF ECONOMIC RESEARCH
1050 Massachusetts Avenue
Cambridge, MA 02138
June 2020

We are very thankful to the George and Obie Shultz Fund for its generous funding and to Gemma Dipoppa for excellent research assistance. We also thank the implementing organization for participating in this project. Benjamin Olken, Joshua Angrist, Daron Acemoglu, Kasper Hansen, and participants in the 2016 APSA Meeting gave invaluable feedback about the study - we are grateful to them. The views expressed herein are those of the authors and do not necessarily reflect the views of the National Bureau of Economic Research.

At least one co-author has disclosed a financial relationship of potential relevance for this research. Further information is available online at http://www.nber.org/papers/w27433.ack

NBER working papers are circulated for discussion and comment purposes. They have not been peerreviewed or been subject to the review by the NBER Board of Directors that accompanies official NBER publications.

(C) 2020 by Enrico Cantoni and Vincent Pons. All rights reserved. Short sections of text, not to exceed two paragraphs, may be quoted without explicit permission provided that full credit, including $\odot$ notice, is given to the source. 
Do Interactions with Candidates Increase Voter Support and Participation? Experimental Evidence from Italy

Enrico Cantoni and Vincent Pons

NBER Working Paper No. 27433

June 2020

JEL No. C93,D72

\begin{abstract}
We test whether politicians can use direct contact to reconnect with citizens, increase turnout, and win votes. During the 2014 Italian municipal elections, we randomly assigned 26,000 voters to receive visits from city council candidates, canvassers supporting the candidates' list, or to a control group. While canvassers' visits increased turnout by 1.8 percentage points, candidates' had no impact on participation. Candidates increased their own vote share in the precincts they canvassed, but only at the expense of other candidates on the list. This suggests that their failure to mobilize nonvoters resulted from focusing on securing the preferences of active voters.
\end{abstract}

\author{
Enrico Cantoni \\ University of Bologna \\ Department of Economics \\ Piazza Scaravilli 2, Bologna \\ Italy \\ enrico.cantoni@unibo.it \\ Vincent Pons \\ Harvard Business School \\ Morgan Hall 289 \\ Soldiers Field \\ Boston, MA 02163 \\ and NBER \\ vpons@hbs.edu
}




\section{Introduction}

Strong electoral participation is commonly considered an essential component of a healthy democracy, both inherently and to ensure equality of representation (e.g., Franklin et al., 2004; Lijphart, 1997). Yet, voter turnout in most of the established democracies has been decreasing over the last decades (Teixeira, 1992; Blais, 2010; Solijonov, 2016). Today, elections in these countries regularly attract less than half of the voting-age population (Lijphart, 1997; Taylor et al., 2014), raising concerns for the representativeness of elected officials and public policies, and for the overall legitimacy and stability of the democratic regimes.

Education and income, which in industrialized countries are positively associated with individual participation (Verba and Nie, 1972; Wolfinger and Rosenstone, 1980; Brady et al., 1995), have risen at the same time overall turnout has declined, making this trend hard to explain. Possible causes include economic adversity (Radcliff, 1992), lowering the voting age (hence increasing the number of eligible voters and, with it, the abstaining percentage) (Franklin et al., 2004), decreased electoral competitiveness (Johnston, Matthews, and Bittner, 2006), deterioration of voter mobilization (Gray and Caul, 2000), and changes in values, attitudes, or family structure (Putnam and Pharr, 2000; Wattenberg, 2002; Dalton, 2007; Blais and Rubenson, 2013; Bhatti et al., 2018). Of particular relevance to this study is one change in values that has been concomitant to the decline in turnout: citizens' increased skepticism about politicians' responsiveness to their concerns. In Italy, where our study takes place, the proportion of voters who think parties do not care about people's opinions grew from $68 \%$ in 1968 to $90 \%$ in $2013 .{ }^{1}$ This fraction is high today in most advanced democracies. In the United States, the fraction of citizens agreeing with the statement that "public officials don't care much what people like [you] think" increased from 35\% in 1952 to $61 \%$ in 2012. Similarly, in France, in $2013,87 \%$ of the population shared the belief that politicians

\footnotetext{
${ }^{1}$ See ITANES (1968), question 148 (http://www.itanes.org/wp-content/uploads/2012/06/ ITA1968_questionarioenvers2005.pdf, retrieved June 7, 2020) and ITANES (2013), question d38_4 (http://www.itanes.org/wp-content/uploads/2014/08/ITA2013_QuestionarioCAPI.pdf, retrieved June 7, 2020).
} 
care little about what they think, up from $42 \%$ in $1977 .^{2}$ Strikingly, citizens expressing such discontent systematically report a significantly lower propensity to vote (Blais and Rubenson, 2013), and distrust of public officials and low turnout further correlate with lack of campaign contact with candidates and their teams. ${ }^{3}$

If these correlations reflect actual causality, then politicians could help reverse the trend of declining turnout by "bridging the gap" with voters, particularly by reducing physical distance and engaging more often in personal interactions with them. ${ }^{4}$

We test this hypothesis with a field experiment conducted in a middle-sized city in Northern Italy during the 2014 municipal elections. These are characterized by mayoral candidates and by party lists - rosters of candidates affiliated with either national political parties or local civic organizations - competing for at-large seats on city councils. The experiment was implemented in partnership with one of the civic (not party-affiliated) lists, and included 38 precincts and 2,612 addresses housing 26,352 registered citizens. ${ }^{5}$ We randomly assigned the addresses in this sample to receive the visits of pairs of candidates on the party list (henceforth the candidates group), the visits of pairs of paid volunteers (henceforth the volunteers group), or to the control group, which did not receive any visit. Assignment probabilities to either type of canvassing or to the control group were respectively one fourth and one half. We also randomized which candidates and volunteers covered which precincts. Since voters chose not only a party list, but also could express preferences for specific candidates within that list, we are able to separate the impact of candidates' visits on their own vote tally and on the votes received by their list mates.

Our study builds on a large experimental literature pioneered by Gosnell (1930) and Gerber

\footnotetext{
${ }^{2}$ See ANES Time Series Studies, question VCF0609 (http://electionstudies.org/studypages/ download/datacenter_all_NoData.php, retrieved June 7, 2020) and TNS Sofres and Cevipof, Baromètre de la confiance politique (http://www.tns-sofres.com/sites/default/files/ 2010.01.15-confiance-politique.pdf and https://www.sciencespo.fr/cevipof/ sites/sciencespo.fr. cevipof/files/BJ9724\%20-\%20CEVIPOF $20-\% 20$ Barome $\%$ CC 80 tre\% 20 confiance $\% 20$ en 20 politique $\div 20 v a g 5 \% 20 \mathrm{VF}$. pdf, retrieved June 7, 2020), respectively.

${ }^{3}$ See ITANES (2013), questions d38_4 (distrust of public officials), d86 (turnout), and d68 (having been contacted); and ANES Time Series Studies, questions VCF0609, VCF0702, and VCF9030a.

${ }^{4}$ Arceneaux (2007) finds that voters visited by a candidate become more likely to think that she is a strong leader. This shows that personal contacts with candidates can change the beliefs that voters hold about them.

${ }^{5}$ Henceforth, we talk interchangeably of addresses and buildings.
} 
and Green (2000). Door-to-door canvassing by regular citizens has been found to sizeably impact electoral participation and vote shares, whether the canvassers are paid or not, and whether their message is civic or partisan (e.g., Arceneaux and Nickerson, 2010; Gerber et al., 2003; Green et al., 2003; Green and Gerber, 2015; Michelson, 2005; Nickerson et al., 2006). Direct contact with politicians may trigger yet larger effects, in particular for low-propensity voters who are otherwise more difficult to mobilize (Arceneaux and Nickerson, 2009; Enos et al., 2014; Enos and Hersh, 2015). Politicians may be better able than regular canvassers to convey information on their policy position. In addition, their visits may reveal personal attributes, improve voter recall, reduce social distance (Hoffman et al., 1996), and signal care for voters' preferences. (For theories of costly signaling applied to electoral campaigns, see for instance Potters et al., 1997 and Ashworth, 2006.)

Empirical evidence on the impact of politicians' direct interactions with voters is still relatively scarce, though such interactions are not unusual even in large municipalities. ${ }^{6}$ For obvious strategic reasons, candidates and elected representatives are typically unwilling to delegate to researchers (and chance) the decision of which citizens to address and how. A notable exception is a study by Wantchekon (2003), which exposes randomly selected villages in Benin to presidential candidates' meetings emphasizing clientelistic vs. public policy platforms and finds the former to generate larger electoral support. More similar to the present study are two experiments involving one-on-one interactions between a single candidate and voters. Arceneaux (2007) does not find any significant effect of door-to-door canvassing by a candidate on voter turnout and Barton et al. (2014) find a negative effect on this outcome. Both studies report substantial impacts on voter support. This outcome is however measured using self-reports from phone surveys. As a result, answer rates are low (respectively 25 and 15\%) and answers may suffer from misreporting, including overreporting for the winner (e.g., Wright, 1993; Atkeson, 1999; Campbell, 2010). The main concern is that respondents' selection and misreporting might differ between treatment and control individuals (Bailey et al., 2014; Cardy, 2005; Gelman et al., 2016).

\footnotetext{
${ }^{6}$ According to a 2009 Boston Globe poll, for example, a surprising $57 \%$ of Boston residents had personally met mayor Thomas Menino during his then 16 years in office (http://www.scribd.com/doc/15123803/ Mayor-election-poll, retrieved February 23, 2015).
} 
The first main contribution of our paper is to estimate the impact of door-to-door visits by multiple candidates on voter turnout, in an election with proportional representation, and to compare that effect to the impact of volunteers' visits to an identical group of voters. Much of the preexisting get-out-the-vote literature has found large effects of door-to-door canvassing across a large variety of settings (Green and Gerber, 2015). However, a small set of experiments conducted in Western Europe find substantially smaller effects than in the U.S, due perhaps to higher baseline turnout leading to a ceiling effect (Bhatti et al., 2018; Foos and John, 2018; John and Brannan, 2008; Nyman, 2017; Pons, 2018; Pons and Liegey, 2019). In addition, most of the existing evaluations of mobilization campaigns examine nonpartisan interventions. But partisan field campaigns, such as in the present study, have been found to generate weaker effects, including in the U.S. (Gerber and Green, 2017; Green et al., 2013a). In light of this evidence, we included the volunteers' treatment group to provide a benchmark. The impact of volunteers' visits would capture the influence of our specific study context, and subtracting this effect from the effect of candidates' visits would isolate the contribution of the candidates' presence. We were expecting this contribution to be positive, but found the opposite. Strikingly, while volunteers' visits increased participation by a significant 1.8 percentage points, amounting to a complier average causal effect and a mobilization rate of $5.01 \%$ and $19.8 \%$, respectively, candidates' visits affected neither the average voter, nor any subgroup of the population, whether defined by age, gender, place of birth, or turnout history.

Our second main contribution is to shed light on the plausible reasons of the differential impact of volunteers and candidates. We exploit the fact that multiple candidates and volunteers were involved in the experiment. Prior studies have found that activists' characteristics (Landry et al., 2006; Price, 2008; Sinclair et al., 2007) and the way in which they interact with citizens (Nickerson, 2007) can substantially affect the impact of the campaign. Does candidates' failure to increase voter turnout reflect lower competence than volunteers? Responses to a survey administered to both candidates and volunteers reveal instead that the candidates were more politically informed, engaged, and experienced. In addition, more politically competent candidates were not more successful at mobilizing voters. Systematic treatment heterogeneity along canvassers' char- 
acteristics is only observed among volunteers, and it goes in the opposite direction: less politicized volunteers had larger effects on turnout.

If candidates' intrinsic quality does not explain their failure to mobilize nonvoters, then perhaps the way they allocated their effort does. Official results at the precinct level reveal that candidates successfully increased their own vote count in the precincts they canvassed. Strikingly, this persuasion effect was obtained at the expense of other candidates on their party list, whose vote counts decreased by an almost equal amount. This result is consistent with voters having clear preferences over parties but weak preferences over candidates within parties (Blom-Hansen et al., 2016). It suggests that candidates may have free-ridden on voter mobilization and put more effort in se-

curing the direct preferences of active voters supporting the list, a strategy that was perhaps less costly but beneficial to them only, not to the rest of their list. We discuss possible interpretations of our results and the broader lessons that can be learned from them in the last section of the paper.

\section{Research Setting}

\subsection{The 2014 Italian Municipal Elections}

We conducted our experiment during the 2014 campaign for the European and municipal elections in Italy. On May 25, every EU citizen 18 or older living permanently in Italy was called to elect the Italian members of the European Parliament. Voters of approximately half of all Italian municipalities, including the one where the experiment was administered, were also called to vote for municipal elections. In municipalities holding both European and municipal elections, there is a unique voter turnout record for the two races: although theoretically possible, it is extremely rare for voters to vote for one, but not for the other race (there are fewer than 20 recorded instances of this phenomenon in our data).

Through municipal elections, Italian voters elect both the mayor and members of the city council, which are respectively the head of the executive and the legislative branches of the municipal government. Voters cast a ballot for a mayoral candidate, and the candidate that receives the largest 
number of votes gets elected. ${ }^{7}$ In all Italian cities with 15,000 residents or more, voters can also choose one of the lists competing for at-large seats in the city council. Typically political parties have one mayoral candidate, and the lists affiliated with those parties back their candidates, while "civic lists" (liste civiche) affiliated with civic organizations throw their weight behind the candidate who best represents their interests. Which lists support which candidates does not constrain voters' choice: voters can choose a list that supports a different mayoral candidate than the one they vote for. Each list receives a number of seats proportional to its vote share, with a minimum of $60 \%$ of the seats allocated to the party lists that supported the winning mayoral candidate. ${ }^{8}$

Then, similarly to municipal and legislative elections in several other countries including Austria, Belgium, and Greece (ECPRD, 2000), the allocation of seats to individual candidates is determined by an open party list method. ${ }^{9}$ That is, when choosing a party list, voters also have the option to express up to two preferences for members of the list, one male and one female. If a voter expresses two preferences for candidates of the same gender, the second preference is considered void. Seats won by the list are allocated to the city council candidates who received the highest number of individual votes. If two candidates are tied for a seat, it goes to the candidate with a higher ranking as determined by the party or organization that put forth the list.

\footnotetext{
${ }^{7}$ In cities with 15,000 residents or more, if no mayoral candidate receives more than $50 \%$ of the valid votes in the first round, the two candidates who get the highest vote share compete in a runoff, which takes place two weeks later. There was no runoff in the municipality studied in the experiment, as the winning mayoral candidate received more than $50 \%$ of the first-round votes.

${ }^{8}$ The party lists that support the winning mayoral candidate receive a number of seats equal to the maximum between $60 \%$ and the sum of their respective vote shares and divide them proportionally. The remaining seats are allocated to lists that supported other mayoral candidates.

${ }^{9}$ Beyond elections using an open party list method, our results likely hold lessons for other types of elections using proportional rule, particularly when voters can express direct preferences for individual candidates, like in German parliamentary elections (in which voters can choose both a list and a specific candidate) and in U.S. municipal elections with single transferable vote. This latter system, also called multi-winner ranked-choice, was used during the 20th century in several U.S. cities including Cincinnati, Cleveland, and New York, and it is currently used in Cambridge and Minneapolis, among others. It is similar to the voting rule used in Italian municipal elections in that it combines proportional representation with direct preferences for candidates (voters have to rank the candidates in order of preference).
} 


\subsection{Candidates' Campaign Incentives under Proportional Representation}

Candidates' campaign incentives in elections with proportional representation differ in at least three ways from their incentives under plurality rule. First, because plurality rule elections are winner-take-all, individual candidates have strong incentives to put effort into the campaign in close races, and weak incentives in lopsided elections. Instead, under proportional representation, competing lists generally care about electing as many list members as possible, not just about obtaining a plurality of them. Winning an additional seat increases the list's influence in the newly elected assembly and it allows the list to reward one additional running mate. Because the number of seats increases proportionally to the vote share, campaign incentives exist even in non-competitive elections and for small lists.

Second, the number of competing candidates tends to be lower under plurality rule. Indeed, weaker candidates will often prefer to stay out of the race since they know that they will leave the election empty-handed unless they obtain a plurality of the votes; moreover, they can expect a large fraction of voters to strategically vote for the front-runners (Duverger, 1954; Cox, 1997). U.S. plurality rule elections which regularly oppose only two candidates, respectively from the Republican and the Democratic party, are a case in point. Instead, small lists may be encouraged to run when seats are allocated proportionally to vote shares, as long as they can reasonably hope to win at least one seat. Unlike well-established parties, new entrants need to establish name recognition, if they want to win any votes, further increasing their incentives to campaign. In our

study context, this is especially true for civic lists, which may support a well-known candidate for mayor and include running mates enjoying some individual notoriety, yet are often formed just before the election and do not campaign under a well-identified party label.

Third, candidates running on a list face a collective action problem which is absent from singlemember districts. Indeed, some of the benefits of individual candidates' campaigning efforts likely accrue to their running mates. In contrast to the two previous points, the failure to internalize this return may reduce their willingness to contribute to the campaign. In Italian municipal elections, the fact that voters can express preferences for individual members of the list alleviates this problem 
and it may actually create incentives for candidates to direct their efforts at obtaining voters' direct preferences instead of increasing their list's overall vote share.

While the overall intensity of the campaign may vary due to differential incentives associated with plurality and proportional elections, the desirability of different types of campaigns should be expected to depend on factors independent from the voting rule, such as the baseline level of participation. Voter turnout in Italy is higher than in the United States and most European countries, but it has been experiencing a steady decline since the late 1970s (Figure 1). Participation at the local and European elections is usually lower than at the higher-salience national parliamentary ones, and the May 2014 European and municipal elections were no exception. Turnout was 57.2\% countrywide, down from $75.2 \%$ in the February 2013 national elections, and from $65.1 \%$ in the 2009 European and municipal elections.

Despite the declining turnout, Italian political parties are not adjusting their campaign methods. While they once used intensive personal contacts, for several decades they have been relying primarily on impersonal methods, such as hanging posters in public spaces, handing out fliers at markets and bus stops, or dropping leaflets in mailboxes (Ballini and Ridolfi, 2002; Novelli, 2018). Similarly as in other European countries (Liegey, Muller, and Pons, 2013), door-to-door canvassing and other field mobilization techniques relying on direct, personal contacts with voters are largely underused today in Italy, and little is known about their effects in that country. ${ }^{10}$

\subsection{The Implementing Organization}

The experiment took place in a municipality in Northern Italy that had almost 30,000 registered voters. The 2014 municipal election in this city featured four mayoral candidates. Of the 11 party lists competing for 24 city-council seats, six supported the main left-wing mayoral candidate. Four of these left-wing lists were endorsed by national political parties, and two were affiliated with local organizations created for the purpose of participating in the municipal elections. The experiment was organized in partnership with one of these two civic lists. Although the cooperating party list

\footnotetext{
${ }^{10}$ To the best of our knowledge, Galasso and Nannicini (2018) is the only other canvassing experiment run in Italy.
} 
was part of a broader coalition, the experiment involved neither the other lists nor the mayoral candidate: the focus of the experiment and of the conversations with the voters was the race for the city council. While the mayoral candidate supported by the list won the election with $62.4 \%$ of the votes, the cooperating list received $3.6 \%$ of all cast votes, making it the second most voted list across the six lists supporting this candidate (after the Partito Democratico, which swept an absolute majority of all cast votes). This resulted in an average of 18.3 votes and 16.5 preferences expressed in favor of the list's candidates in each precinct, and in one one of its candidates obtaining a seat at the city council.

The cooperating list had comprised 20 candidates to the city council, including the former deputy mayor, a former member of the municipal executive branch, and two incumbent city councilors. Eleven candidates on the list took part in canvassing activities, along with eleven volunteers. These volunteers were either students or recent graduates of the nearby university, and they received a compensation of 8.5 euros per hour. Towards the end of the experiment, we administered a survey to all volunteers and candidates. We used the survey to collect socio-demographic information about the canvassers, their feedback on the field campaign, and to assess their level of political competence. Panel A of Table 1 presents the main socio-demographic characteristics. Volunteers are on average younger and more educated than candidates, which is not surprising as they were all selected among masters students or recent graduates.

However, volunteers display a lower level of political engagement and competence than candidates (Table 1, Panel B). Only about half of them had voted in the most recent national or municipal elections, and none of them had ever held any public office. Conversely, all candidates had voted in both elections, and one third had previous experience in elective public offices. Similarly, volunteers reported spending less time gathering political information from different media outlets, with the exception of the internet, and they were less likely to know the name and party of the Minister of Foreign Affairs. ${ }^{11}$ Following Kling et al. (2007), we summarize the information from Panel $\mathrm{B}$ with a single index of political engagement, defined to be the equally weighted average of the

\footnotetext{
${ }^{11}$ Quite surprisingly, however, while all volunteers and candidates got the name of House President right, most candidates failed to identify her party.
} 
Z-scores of its components. Let $\alpha_{k}(k=1, \ldots, 12)$ denote the responses to the 12 questions reported in Panel B (which are coded so that higher values correspond to higher engagement/awareness), and $\mu_{k}$ and $\sigma_{k}$ be the unweighted mean and standard deviation of $\alpha_{k}$ across all volunteers and candidates. Our summary index is then defined as $(1 / 12) \sum_{k=1}^{12}\left(\alpha_{k}-\mu_{k}\right) / \sigma_{k}$. By construction, the overall mean of the index is 0 . However, the mean for the volunteers is negative while the mean for the candidates is positive, confirming their larger degree of political engagement and competence.

\subsection{The Treatments}

We conducted the experiment in 38 of the 39 electoral precincts of the municipality. ${ }^{12}$ All 26,352 voters living in the 38 sample precincts and their 2,612 addresses, indicated in the voter register, were included in the experiment. A large fraction of addresses contained multiple apartments. The treatment was assigned at the address level after stratifying for precinct and street name, so that all apartments of a given address were allocated to the same treatment condition by construction. Each address had a one fourth probability of being assigned to either of the two treatment groups, and one half probability of being assigned to the control group. Door-to-door visits by candidates and volunteers took place during the five weeks before Election Day. We asked canvassers to knock on doors in pairs of two to increase their safety and motivation. In our view, this also increased the chance that voters who received the visit of canvassers would have an affinity with at least one of them and, as a result, that they would be willing to engage in a discussion with them. Canvassers visiting apartment buildings were instructed to buzz private intercoms and request permission to access the building. When they managed to enter, canvassers knocked on the door of every apartment. Treatment delivery was attempted only once for each address and, within the address, for each apartment: if nobody opened the door, canvassers would move on to the next one and not come back. Our field research assistant monitored both groups of canvassers to ensure adherence to the experimental protocol on a daily basis throughout the entire campaign.

All volunteers devoted approximately the same time to the door-to-door campaign. We were

\footnotetext{
${ }^{12}$ One precinct was excluded from the sample due to lack of individual turnout data for the 2013 national elections.
} 
thus able to pair them in teams of two that were mostly stable throughout the campaign. Differently from the volunteers, the intensity of the involvement of candidates varied greatly. Before the experiment, six candidates committed to dedicate considerable time to canvassing, while the five other committed less time to it. Each evening in which a dedicated candidate was active, she was paired with one of the less-involved candidates also available that evening. Pairs of candidates were formed in an effort to compose complementary teams. In particular, to the extent possible, each team comprised a man and a woman. In addition to making the team complementary, this responded to a request of the candidates, who wanted to ensure that the citizens would be able vote for both candidates in the team, if they so chose. ${ }^{13}$

In addition to randomizing the allocation of addresses to the control, candidates, and volunteers groups, we also randomized which dedicated candidates and pairs of volunteers covered which precincts. The choice of the first four precincts covered by the campaign was based on their location (as close as possible to the meeting point to facilitate the supervision of the canvassers by the research team on the first day of the campaign). In each treatment group, these four precincts were randomly allocated to the canvassers. The remaining 34 precincts were assigned to canvassers based on a random order. That is, whenever a couple of volunteers or a dedicated candidate finished covering a precinct, they were assigned the next untouched precinct in the (randomly ordered) list, resulting in random allocation.

Due to lack of time, the candidates only canvassed $70 \%$ of their assigned addresses, while the volunteers canvassed all the addresses assigned to them. Because we instrument canvassing by candidates with our exogenous instrument (i.e., being assigned to receive a visit by candidates), partial treatment delivery in the candidates' group poses no threat to causal identification of turnout effects. Moreover, candidates did not "choose" the $70 \%$ of assigned addresses they eventually canvassed: the randomization of the order with which precincts would be canvassed left no discretion to canvassers over which areas (and thus voters) to canvass earlier or later. ${ }^{14}$

\footnotetext{
${ }^{13}$ When the number of involved candidates exceeded the number of less involved candidates available on a given day, volunteers or our research assistant were paired with them. In these heterogeneous teams, the candidate was responsible for leading the conversation with the voters.

${ }^{14}$ With power $80 \%$, ex-post Minimum Detectable Effects (MDEs) of candidates' and volunteers' visits at the $5 \%$
} 
Volunteers and candidates received the same training prior to the campaign. They all received the same toolkit with detailed instructions on how to conduct the discussions with voters (see Appendix A.4 and A.5). As in most GOTV interventions, the instructions we provided were intended as a general canvass, which would be adapted according to each voter's questions and interests. As Green and Gerber (2015) note in their seminal book on GOTV campaigns, scripts are helpful to guide canvassers, but they are not a substitute for informal and personalized discussions, which contribute to the effectiveness of door-to-door canvassing. The canvassers were instructed to actively engage voters in discussions about politics and the civic list, and to provide them with information about the upcoming elections. Canvassers gave general information on how to vote and more specific instructions on how to cast their votes for city council candidates. They emphasized that the election would be the first nationwide election in 13 years to be held on a single day (Sunday), as opposed to both on a Sunday and the following Monday, and provided information about polling station location and opening hours. These conversations had the twofold objective of identifying and mobilizing potential nonvoters, as well as persuading undecided center-left-leaning voters to casting their ballot for the party list. Lists campaigning under the label of a well-established party are easily recognizable by voters, which may facilitate both the mobilization of party supporters and the persuasion of undecided voters. In contrast, the civic list we partnered with could only hope to win votes through persuasion or mobilization if it first acquired a minimal level of name recognition. At the beginning of each conversation, candidates and volunteers introduced themselves as city council candidates of the civic list and volunteers working for that list, respectively. At the end, they distributed a leaflet customized with the logo of the campaign and the key points of the list's platform (see Appendix A.6 and A.7). Candidates had prepared personalized cards, which contained their name and instructions on how to cast votes for candidates in the city council race, and they attached these to the leaflets.

level are 2.1 and 2.2 percentage points, respectively. The higher MDE for the candidate treatment reflects the incomplete treatment delivery in this arm. The MDE for the average effect across the candidate and volunteer treatments is approximately 1.8 percentage point. Finally, the MDE for the difference between impact estimates of the candidate and volunteer treatments is 2.6 percentage points. All these ex-post MDEs account for randomization strata (street name by precinct) and for treatment assignment at the residential address level. 
Even though we gave the same training to both groups of canvassers, and even though our research assistant frequently reminded them that mobilization of nonvoters and persuasion of active voters were simultaneous objectives of the campaign, there is suggestive evidence that volunteers spent slightly more time and effort mobilizing nonvoters, while candidates focused a bit more on persuasion instead. Overall, the time spent in front of each opened door (including the time to move from one address to the other) was 7.2 minutes for volunteers and 7.8 for candidates. However, whereas volunteers' visits were relatively shorter in areas characterized by high past turnout (6.9 minutes across all opened doors vs. 7.6 in areas with lower-than-average turnout in 2013), the opposite was true for the candidates (8.0 across all vs. 7.5 in low-turnout). ${ }^{15}$ Moreover, in the openended part of the survey most candidates reported trying to secure the voters' personal preferences and dissuading them from voting for other left-wing parties. Overall, candidates reported a good level of satisfaction with how they were greeted by voters. By contrast, volunteers were generally unsatisfied with how they were treated by voters, but they reported being greeted more favorably when they were perceived as "combating abstentionism" (even if in the context of a list's electoral campaign) than as trying to "win new votes" for the party list.

\section{Results}

\subsection{Verifying Randomization}

Randomization ensures that all observable and unobservable characteristics are balanced across assignment groups. Table 2 verifies covariate balance across the candidates group, volunteers group, and control group for a series of characteristics available from the voter rolls and for turnout in the 2013 national elections. We present summary statistics for registered voters in the control group (column 1) and show estimates of the difference between the control group and, respectively,

\footnotetext{
${ }^{15}$ Areas with high (resp. low) past turnout are defined as (i) collections of buildings visited by a team of canvassers on a single day, and (ii) where average turnout at the 2013 national elections was higher (resp. lower) than the median $(81.3 \%)$. Because we do not know the exact amount of time spent in front of each door, average visits' durations are computed using the total number of open doors in the two treatments and the estimated time canvassers spent on the field (i.e., an average of 2 and 3.5 hours per canvassing session on weekdays and weekends, respectively).
} 
the volunteers group, the candidates group, and any of the two treatment groups in columns 2, 3 , and 4. Overall, registered voters across groups are extremely similar. Out of 33 differences reported in Table 2, only three are significant at the 5\% level, and four are significant at the $10 \%$ level, which is in line with what should be expected.

The average voter in the control group is 55 years old and lives in a building of 20 registered voters. $52 \%$ of the control group voters are females, $63 \%$ are married or widows/widowers, $64 \%$ were born in the province, and only $3 \%$ were born abroad. ${ }^{16}$ The vast majority of voters participated in the 2013 national parliamentary elections, while $6 \%$ were not on the 2013 voter rolls, either because they were too young at the time or because they were registered elsewhere.

In Table 3, we verify the random allocation of canvassers to precincts and show that canvassed voters' characteristics exhibit little correlation with the level of political competence of the canvassers who visited their addresses. We do so separately for voters whose addresses were visited by volunteers (column 1), by candidates (column 2), or by canvassers of either type (column 3). Each cell reports estimates and standard errors from a bivariate regression of the row variable, which represents a characteristic of canvassed voters, on the average political engagement $\mathrm{z}$-score of the visiting canvassers. Since volunteers covered more precincts than candidates (therefore potentially visiting, on average, different sets of voters), regressions in column 3 control for treatment assignment dummies. In these and all other regressions that exploit the random allocation of canvassers to voters, standard errors are clustered at the precinct level. The random allocation of precincts to canvassers produced a fairly balanced distribution of canvassers' political competence across different types of voters. In line with expectations, only three of the 33 regression coefficients in Table 3 are significant at the $10 \%$ level, and none is significant at the $5 \%$ level. ${ }^{17}$

\footnotetext{
${ }^{16}$ Voter records for women indicate whether the voter is currently married or widowed. By contrast, voter records for men only indicate the spouse's name, regardless of whether she is alive or deceased.

${ }^{17}$ Appendix Table A.3 reports the precinct-clustered asymptotic p-values of these balancing exercises, along with wild bootstrap p-values robust to clustering by precinct and by each of the two canvassers who canvassed a given address. Wild bootstrap p-values are substantively in line, albeit slightly larger, than their asymptotic precinct-clustered counterparts.
} 


\subsection{Voter Mobilization}

Main Effects. We first examine the impact of the visits on voter turnout. We measure individual participation using official attendance sheets which were signed by election officers in charge of identifying voters at the polling station. We took pictures of these sheets and digitized them. ${ }^{18}$ Table 4 reports results of regressions of the following form:

$$
\operatorname{Vote}_{i}=\alpha+\beta^{v} T_{b(i)}^{v}+\beta^{c} T_{b(i)}^{c}+X_{i, b(i)}^{\prime} \lambda+\sum_{s} \delta_{b(i)}^{s}+\varepsilon_{i}
$$

where Vote $_{i}$ equals 1 if voter $i$ living in building $b(i)$ turned out to vote on Election Day, and 0 otherwise; $T_{b(i)}^{v}$ and $T_{b(i)}^{c}$ are dummies for whether building $b$ received the visit of volunteers or candidates, respectively; $X_{i, b(i)}$ is a vector of voter and building characteristics; and $\delta_{b(i)}^{s}$ are strata fixed effects. As discussed above, only $70 \%$ of the buildings assigned to the candidates were eventually visited. We therefore instrument $T_{b}^{c}$ with a dummy for assignment to the candidate treatment. The coefficients of interest are the $\beta^{t}$ 's, which represent the average difference in turnout between residents of buildings that received treatment $t$ and voters in the control group. The $\beta^{t}$ s are not adjusted to take into account the fraction of opened doors, respectively $45.5 \%$ and $35.9 \%$ in the candidates' and volunteers' groups. In this and all other voter-level regressions that do not exploit the random assignment of precincts to canvassers, standard errors are adjusted for clustering at the building level since the randomization was conducted at this level.

As shown in column 1 of Table 4, voters living in buildings canvassed by volunteers had a turnout rate 1.8 percentage points higher than voters in the control group. This difference is statistically significant at the 5\% level and robust to controlling for baseline covariates (column 2). By contrast, visits by candidates did not have any significant impact on turnout. Voters living in buildings canvassed by candidates were (an insignificant) 0.2 percentage point less likely to vote on Election Day than their counterparts in the control group. Both with and without baseline co-

\footnotetext{
${ }^{18}$ Voter turnout sheets were available for all 38 precincts except for female voters of one precinct (turnout sheets are maintained separately for male and female voters). As a result, voter-level regressions exclude female voters from this precinct. All balance tests are unaffected by including these female voters. Similarly, precinct-level regressions are unaffected by the exclusion of the corresponding precinct. Results available upon request.
} 
variates, we reject the hypothesis of joint insignificance of the two treatment effects at the 5\% level ( $p$-values of 0.041 and 0.028 ), and the hypothesis of equality of effects at the $10 \%$ level ( $p$-values of 0.084 and 0.055$)$. Estimates for the baseline covariates reported in column 2 are in line with the existing literature: older, married, local and politically active voters are more likely to vote, and the contrary holds true for widows, foreign-borns and voters who didn't participate in the higher-salience 2013 national elections.

Our estimates can be compared to the existing literature using the method proposed by Green et al. (2013b) and the one suggested by DellaVigna and Gentzkow (2010). For the first method, we estimate the Complier Average Causal Effects (CACE) by dividing our estimated treatment effects by the fraction of opened doors. We obtain CACEs of, respectively, $0.018 / 0.359=5.01 \%$ and $-0.002 / 0.455=-0.4 \%$ for the volunteer and candidate treatments. For the second method, we further divide CACEs by the proportion of voters that could potentially be mobilized to vote by the treatment (i.e., 1 minus the fraction of nonvoters in the control group). We obtain mobilization rates of, respectively, $0.018 /(0.359 \times(1-0.747))=19.8 \%$ and $-0.002 /(0.455 \times(1-0.747))=$ $-1.7 \%$ for the volunteer and candidate treatments. According to both methods, the effect of volunteers' visits is of the same order of magnitude as the largest mobilization rates documented by existing studies on the impact of door-to-door canvassing on voter turnout (DellaVigna and Gentzkow, 2010; Green et al., 2013b). Though insignificant, the negative effect of candidates is comparable to the estimates obtained by Barton et al. (2014).

In Appendix A.1, we compute the mobilization rate with an alternative method. We use a 2SLS framework, where the fraction of opened doors is instrumented by treatment assignment; that is, we estimate the local average treatment effect (LATE) of canvassers' visits on voter turnout. The sign, significance, and relative magnitude of the estimates are very similar to those presented in Tables 4 and 5. We prefer the method described in the main text and commonly used in GOTV experiments: the fact that the fraction of doors opened is measured at the building, not the apartment or individual level, makes the interpretation of heterogeneous effects measured along individual socio-demographic characteristics difficult in the 2SLS framework. 
Interactions with Voter Characteristics. Although candidates had no impact overall, it is possible that they successfully mobilized certain types of voters, e.g., the low-propensity ones, while demobilizing others. To explore this possibility, we now examine if treatment effects vary across voters who voted in the 2013 national elections and those who didn't. In the appendix, we also explore interactions with gender, place of birth, and age. Formally, for each variable $Z$, we estimate the following model:

$$
\text { Vote }_{i}=\alpha+\sum_{k} \theta^{v, k} Z_{i}^{k} \times T_{b(i)}^{v}+\sum_{k} \theta^{c, k} Z_{i}^{k} \times T_{b(i)}^{c}+X_{i, b(i)}^{\prime} \lambda+\sum_{s} \delta_{b(i)}^{s}+\varepsilon_{i}
$$

where the $Z_{i}^{k}$, s are mutually exclusive and collectively exhaustive dummies indicating values taken by the variable (e.g., male and female for gender). ${ }^{19}$ Again, to address the incomplete delivery of the candidate treatment, interactions with $T_{b}^{c}$ are instrumented by the corresponding interactions with a dummy for assignment to the candidate treatment.

Table 5 reports the results of the regression interacting the treatment dummies with past turnout, along with the average effects from Table 4, column 2 . For a given value $Z_{i}^{k}$, column 1 provides the average turnout rate of voters in the control group that have $Z_{i}^{k}=1$, whereas columns 2 and 3 report estimates of $\theta^{v, k}$ and $\theta^{t, k}$, respectively. Appendix Table A.4 reports estimates of the regressions interacting the treatment dummies with voter gender, place of birth, and age.

Interestingly, the volunteer treatment produced the largest turnout gains among voters with a higher-than-average propensity to vote: those who voted in the higher-salience 2013 national elections and people born in the province. These results are in line with preexisting findings showing that, in the context of elections of intermediate salience, door-to-door canvassing mostly mobilizes medium- and high-propensity voters (Arceneaux and Nickerson, 2009; Enos et al., 2014). This evidence, however, is mostly suggestive: due to limited statistical power, we cannot reject the null hypothesis that the treatment effect is the same across different values of any socio-demographic

\footnotetext{
${ }^{19}$ Differently from the other socio-demographic characteristics, age is not included as a set of dummies but as a continuous variable, after subtracting 18 years. Also note that we do not add separate notation for the direct effect of the $Z_{i}^{k}$ 's since they are already included in the set of covariates $X_{i, b(i)}$.
} 
variable. Turning to the candidates' treatment, we do not find evidence that it significantly affected voter turnout for any of the subgroups examined in Table 5 (column 2). Like for the average treatment effects, we report the 2SLS counterpart of Table 5 in the Appendix, Table A.1.

Interactions with Canvassers' Political Competence. If not voters' characteristics, then perhaps candidates' characteristics may have influenced the impact of their visits on voter turnout and could explain why only the volunteers' visits were impactful. We thus examine whether candidates or volunteers with different levels of political competence and engagement were more or less effective at mobilizing voters. As described in Section 2, our canvassers' survey included several questions measuring political interest, information, and experience, which we summarize in a single index. We then define the level of political competence of any pair of canvassers as the (demeaned) average of the two canvassers' indices ${ }^{20}$ and run the following regression:

$$
\text { Vote }_{i}=\alpha+\beta^{v} T_{b(i)}^{v}+\beta^{c} T_{b(i)}^{c}+\gamma^{v} I_{b(i)}^{v} \times T_{b(i)}^{v}+\gamma^{c} I_{b(i)}^{c} \times T_{b(i)}^{c}+X_{i, b(i)}^{\prime} \lambda+\sum_{s} \delta_{b(i)}^{s}+\varepsilon_{i}
$$

where $I_{b(i)}^{v}\left(\right.$ resp. $\left.I_{b(i)}^{c}\right)$ is the political index of the volunteers' team (resp. candidates' team) which canvassed building $b . \gamma^{\nu}$ and $\gamma^{c}$ estimate the influence of canvassers' political index on the impact of the visits. Table 6 reports the results, without (column 1) and with (column 2) the same set of voter-level covariates included in Table 4, column 2. More politically competent candidates were not significantly more successful at mobilizing voters. ${ }^{21}$ Systematic treatment heterogeneity along canvassers' political index is only observed for the volunteers, and it goes in the opposite

\footnotetext{
${ }^{20} \mathrm{We}$ use only the candidate's z-score for mixed candidate-volunteer couples, as exclusively the candidate was responsible for leading the conversation. Moreover, we demean z-scores by treatment group so that the main effects are interpretable as the effects of the average canvassing couple in each treatment.

${ }^{21}$ For each estimate, we report both the precinct-clustered asymptotic p-value (in brackets) and the wild bootstrap p-value robust to clustering by precinct and by each of the two canvassers, if any, who canvassed a given address (in braces). To compute wild bootstrap p-values, we replace missing values of the two variables indicating canvassers with a number uniquely identifying control-group observations in a given precinct. Moreover, within each pair of canvassers, we define canvassers 1 and 2 to be, respectively, the female and the male canvasser in the couple. For the relatively few voters ( 747 out of 11,089 voters visited by candidates or volunteers) visited by pairs of canvassers of the same gender, we define canvassers 1 and 2 based on their names' alphabetical order. That is, canvasser 1 (resp. canvasser 2) is the first (resp. second) canvasser within each pair according to the two canvassers' names' alphabetical order.
} 
direction: less politicized volunteers had larger effects on turnout. As shown in Table A.2, these results are robust to using alternative constructions of the political competence index, and the impact of candidates did not systematically vary along their level of education either.

\subsection{Voter Persuasion}

The campaign sought to win votes by mobilizing inactive supporters as well as persuading active but undecided voters. Even though the visits of candidates did not increase participation, they may have persuaded some active voters, thus increasing the number of votes the candidates and/or their list received. As a preliminary check on the existence of persuasion effects, we compare the 25 precincts that were canvassed by candidates to the 13 that were not. Since volunteers canvassed all precincts, and vote counts are not available at any geographical level finer than the precinct, we cannot estimate the impact of their visits on vote shares. Column 1 of Table 7 reports the results of a bivariate regression of precinct-level vote share on a dummy for candidate canvassing. Columns 2 and 4 weight observations by the number of voters living in the precinct. Columns 3 and 4 control for precinct means of voter characteristics. Although the limited sample size rules out clear-cut conclusions, ${ }^{22}$ we find no evidence of persuasion induced by canvassing candidates. If anything, the list vote share decreased by an insignificant 0.3 percentage point in precincts canvassed by candidates. These results are robust to excluding the four precincts which were non-randomly selected to be covered on the first day of the visits, based on their proximity to the meeting point (results available upon request).

When choosing a list, voters can also express up to two preferences for members of the list. We now exploit the fact that different candidates were randomly assigned to different precincts, and use official electoral results on individual candidates' vote counts at the precinct level to disentangle the effect of a candidate's visit on her/his vote tally from the effect on the votes received by the

\footnotetext{
${ }^{22}$ With 25 precincts canvassed by candidates and 13 non-canvassed precincts, the mean list vote share in noncanvassed precincts of 0.0363 , and outcome standard deviations in non-canvassed and canvassed precincts of, respectively, 0.0154 and 0.0160 , the ex-post minimum detectable difference in vote share between canvassed and noncanvassed precincts with $80 \%$ power is 0.0155 .
} 
other candidates on the list. To estimate these two impacts, we run the following regressions:

$$
N V_{i, j}=\alpha+\beta \mathbf{1}(\text { precinct } j \text { canvassed by candidate } i)+\delta_{i}+X_{j}^{\prime} \lambda+\varepsilon_{i, j}
$$

and

$$
\overline{N V_{i, j}}=\alpha+\gamma \mathbf{1}(\text { precinct } j \text { canvassed by candidate } i)+\delta_{i}+X_{j}^{\prime} \lambda+\varepsilon_{i, j}
$$

where $N V_{i, j}$ represents the votes received by candidate $i$ in precinct $j$ and $\overline{N V_{i, j}}$ the votes received in precinct $j$ by all candidates of the list but $i$. The variable of interest is $\mathbf{1}$ (precinct $j$ canvassed by candidate $i$ ), a treatment dummy equal to 1 if precinct $j$ was randomly assigned to be canvassed by candidate $i$. We control for candidate fixed effects $\delta_{i}$ 's, to control for candidate characteristics, such as her/his overall level of renown in the municipality, that might affect her/his vote counts even in absence of canvassing. We run OLS and Poisson regressions, with or without precinctlevel covariates $X_{j}$ or fixed effects, and using one observation per candidate $\times$ precinct, for a total of $760 .^{23}$ The results from regressions 4 and 5 are presented in Table 8.

Columns 1 through 3 report the effect on the canvassing candidates' own vote tallies. Candidates received .85 additional votes (Panel A, column 2) in the precincts they covered, thereby doubling the average of 0.80 votes. OLS estimates that control for precinct-level covariates or fixed effects are significant at the $10 \%$ level. This impact corresponds to $0.44 \%$ of all 180 voters assigned to the candidates treatment in the average precinct. Taking into account the door-opening rate of $45.5 \%$, we obtain that the candidates persuaded $.98 \%$ of voters to give them their preference in households that opened their door. Proportional effects estimated by Poisson and Negative Binomial regressions corroborate a similar, statistically more precise conclusion. For example, the estimate of .689 from Panel B, column 2, implies that a canvassing candidate increased her/his vote tally in the precinct by $e^{.689}-1=99 \%$, which is comparable to the ratio between the corresponding OLS impact estimate and the mean dependent variable (i.e., .853/.804). ${ }^{24}$

\footnotetext{
${ }^{23}$ Since $N V_{i, j}+\overline{N V_{i, j}}=$ TotVotes $_{j}$ (i.e., the sum of the two outcomes is invariant at the precinct level), including precinct fixed effects makes the OLS estimate $\hat{\beta}$ mechanically equal to $-\hat{\gamma}$.

${ }^{24}$ Negative Binomial impact estimates are slightly larger and more statistically significant than their Poisson counterparts. For example, the estimate of 1.049 from Panel C, column 2, implies that a canvassing candidate increased
} 
Columns 4 through 6 show the effect of canvassing candidates' visits on the votes received by all other candidates. Consistently with the null effect on list vote share, candidates' canvassing was essentially a zero-sum game: each new preference obtained by a candidate came from "stealing the votes" of other candidates of the same list. Though at the limit of statistical significance, this finding is robust to a number of different specifications, such as the inclusion or omission of precinct-level covariates, as well as the restriction of the sample to the six more dedicated candidates (see Appendix Table A.6). ${ }^{25}$ While limited statistical power forbids any strong conclusion, ${ }^{26}$ the available evidence suggests that candidates did receive more votes in the precincts they canvassed, but that a sizable share of this effect came from votes "stolen" from fellow list candidates.

\section{Discussion and Conclusion}

Decreasing participation in the United States and in many European countries is paralleled by another trend: a growing number of citizens express skepticism about politicians' responsiveness to their concerns. Partnering with a civic organization that ran a list of candidates for city council seats during the 2014 Italian municipal elections, we test whether discussions between candidates and voters can help bridge this gap and increase voter turnout. The answer is a surprising no: doorto-door visits made by the candidates during the five weeks before the election did not have any significant effect on electoral participation. In addition, we do not find any effect of the candidates' visits on any subgroup of the population, whether defined by age, gender, place of birth, or turnout history. Our results enable us to discuss possible interpretations of the failure of voter mobilization by candidates in this study.

her/his vote tally in the precinct by $e^{1.049}-1=185 \%$. However, unlike OLS and Poisson regressions, Negative Binomial regressions suffer from potential incidental parameters bias (Cameron and Trivedi, 2013). That is, inconsistent estimation of the candidate and/or precinct fixed effects leads to inconsistent estimates of the other model parameters. This suggests caution is needed in interpreting estimated persuasion effects from Negative Binomial specifications.

${ }^{25}$ Remember that, whenever each of the six more dedicated candidates finished covering a precinct, she was assigned the next untouched precinct in the (randomly ordered) list. By contrast, "non-committed" candidates were paired with a dedicated candidate in an attempt to compose complementary teams. Consequently, the treatment for persuasion regressions (i.e., a dummy for being randomly assigned to canvass a certain precinct) has non-zero values only for the six main candidates. All persuasion results are substantively identical when we restrict the sample to all eleven candidates who took part in canvassing activities (results available upon request).

${ }^{26}$ See Table A.7 reporting persuasion MDEs. 
The first possible interpretation is that the particular context of the experiment was not suited to door-to-door canvassing: perhaps voters in Northern Italy simply are not culturally receptive to direct campaign contacts as they are in the United States and in other countries. This interpretation, however, is ruled out by the large and significant impact of similar visits made by volunteers to a comparable group of addresses over the same period. The 1.8 percentage point effect of volunteers' visits implies that $19.8 \%$ of the voters who were successfully contacted by the volunteers and would have abstained otherwise were mobilized to vote, a mobilization rate that compares favorably with the impact of door-to-door canvassing measured in other settings.

A second possible interpretation is that the candidates were not of the type that makes doorto-door canvassing impactful. Prior studies have found that activists' characteristics and the way in which they interact with citizens can substantially affect the impact of the campaign. Candidates of the civic list we worked with were not professional politicians, even though several of them had prior office experience. Were they too incompetent to successfully mobilize nonvoters, thereby limiting also the external validity of the findings? We do not find much empirical support for this explanation. Responses to our survey of all those who conducted visits reveal instead that candidates were more informed and politically engaged than the volunteers. In addition, more politically competent candidates were not more successful at mobilizing voters. Systematic treatment heterogeneity along canvassers' characteristics is only observed for the volunteers, and it goes in the opposite direction: less politicized volunteers had larger effects on turnout.

A last interpretation is that candidates and volunteers acted differently during the visits. Even though the candidates' visits did not impact voter turnout, they increased, modestly but significantly, the number of votes they received as individuals from voters on the day of the election. This suggests that at least some candidates devoted time and efforts to persuade active voters to give them their direct vote, beyond simply voting for their list. Several motives could explain this behavior: the desire to increase their chance to get elected or to gain esteem from other candidates. Evidence about the rolling-out of the door-to-door campaign further supports this claim: candidates spent more time discussing with voters with high- than low-turnout history, they chose to 
systematically pin personalized cards to the campaign leaflets, and men asked to be paired with women, so that voters could give their two preferences to both candidates in the team. Conversely, volunteers were openly supporting the list, but no candidate in particular. We infer that the differential impact of volunteers and candidates on voter turnout may have been partly due to the latter devoting less time and effort to mobilizing nonvoters, and more to obtaining active voters' direct preferences.

Two circumstances make this result particularly striking: nonvoters had been explicitly pointed out, in the training, as a primary target of the campaign. In addition, we find that the persuasion effect benefited the candidates canvassing a particular precinct only at the expense of their list mates. This suggests that candidates' individual incentives can keep them away from mobilizing nonvoters, even when their list or party would benefit from it. This insight may extend beyond the particular setting created by the preferences system in Italian municipal elections: while politicians often lament the growing gap with disgruntled voters, they may simply not have clear individual incentives to take any costly action to close it. Politicians compete against rivals within their own party or camp in many contexts - jockeying for position within the party, competing in primaries for forthcoming elections, and in some elections themselves. In these instances, it may be - or at least seem - more cost-effective to focus on securing the vote and support of affiliated members or active supporters of their party instead of reaching out to disenchanted citizens. Incentives to focus on obtaining active voters' direct preferences instead of mobilizing nonvoters were perhaps particularly strong for the candidates of the civic list we partnered with for this experiment, given its limited electoral prospects. How different electoral rules and party regulations affect politicians' incentives to undertake actions in the interest of their party and to target one type of citizens or another, and how these incentives vary depending on parties' strength is an important topic for future research. 
Figure 1: Turnout in Italy at Parliamentary, European and Municipal Elections

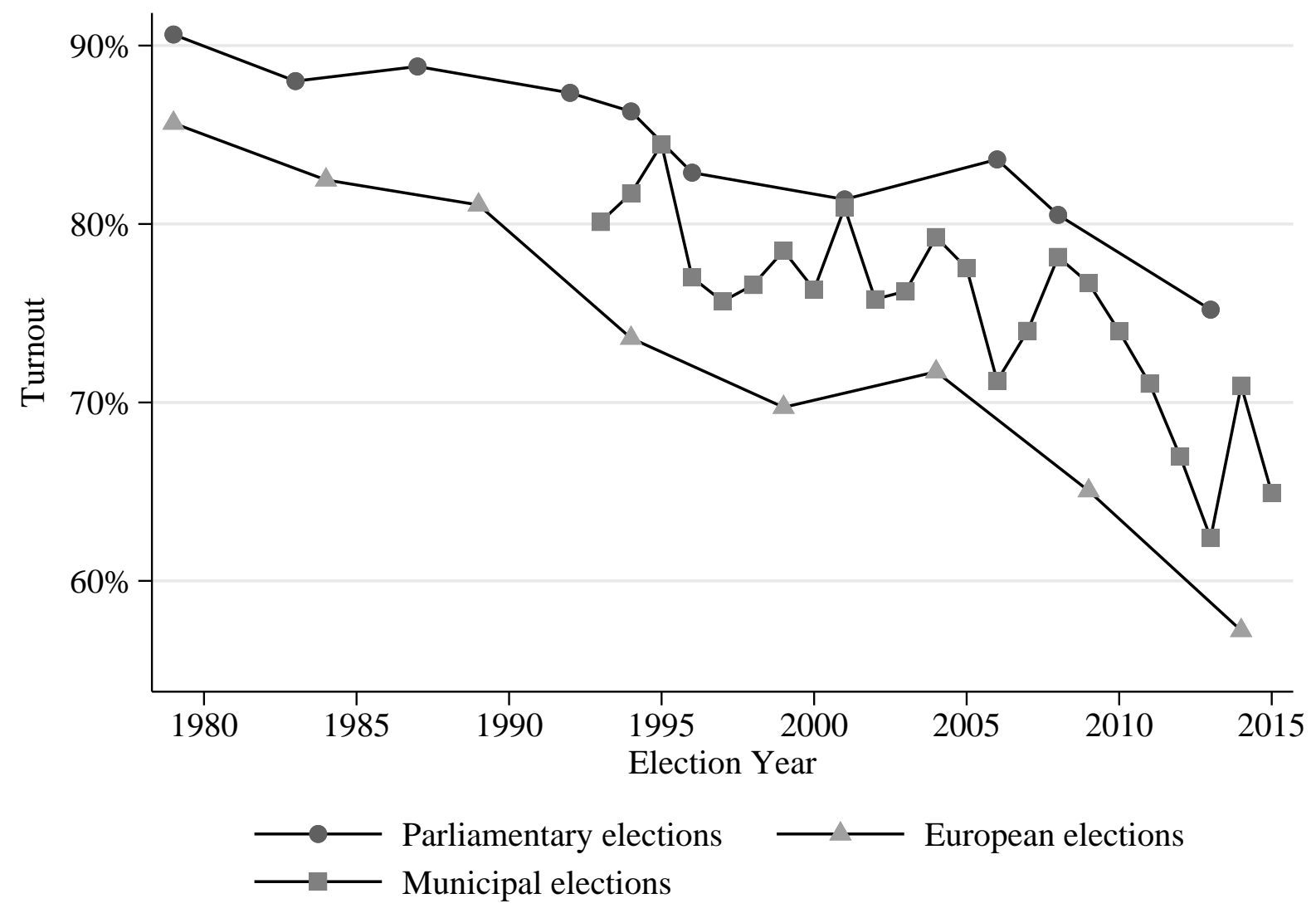


Table 1: Volunteers' and Candidates' Summary Statistics

\begin{tabular}{|c|c|c|c|}
\hline & $\begin{array}{c}\text { Volunteers } \\
(1) \\
\end{array}$ & $\begin{array}{c}\text { Candidates } \\
(2)\end{array}$ & $\begin{array}{c}\text { All Canvassers } \\
\text { (3) }\end{array}$ \\
\hline \multicolumn{4}{|c|}{ A. Socio-Demographics } \\
\hline Age & $\begin{array}{l}25.36 \\
(1.75)\end{array}$ & $\begin{array}{c}47.64 \\
(15.40)\end{array}$ & $\begin{array}{c}36.50 \\
(15.63)\end{array}$ \\
\hline Female & $\begin{array}{c}0.55 \\
(0.52)\end{array}$ & $\begin{array}{c}0.36 \\
(0.50)\end{array}$ & $\begin{array}{c}0.45 \\
(0.51)\end{array}$ \\
\hline Education ( 1 = middle school, 4 = master's degree $)$ & $\begin{array}{c}3.91 \\
(0.30)\end{array}$ & $\begin{array}{c}2.73 \\
(1.10)\end{array}$ & $\begin{array}{c}3.32 \\
(0.99)\end{array}$ \\
\hline \multicolumn{4}{|c|}{ B. Political Engagement/Awareness } \\
\hline Knows the name of Minister of Foreign Affairs & $\begin{array}{c}0.55 \\
(0.52)\end{array}$ & $\begin{array}{c}0.73 \\
(0.47)\end{array}$ & $\begin{array}{c}0.64 \\
(0.49)\end{array}$ \\
\hline Knows the party of Minister of Foreign Affairs & $\begin{array}{c}0.64 \\
(0.50)\end{array}$ & $\begin{array}{c}0.73 \\
(0.47)\end{array}$ & $\begin{array}{c}0.68 \\
(0.48)\end{array}$ \\
\hline Knows the name of House President & 1.00 & 1.00 & 1.00 \\
\hline Knows the party of House President & 1.00 & $\begin{array}{c}0.18 \\
(0.40)\end{array}$ & $\begin{array}{c}0.59 \\
(0.50)\end{array}$ \\
\hline Voted in 2013 national elections & $\begin{array}{c}0.45 \\
(0.52)\end{array}$ & 1.00 & $\begin{array}{c}0.73 \\
(0.46)\end{array}$ \\
\hline Voted in last municipal election & $\begin{array}{c}0.55 \\
(0.52)\end{array}$ & 1.00 & $\begin{array}{c}0.77 \\
(0.43)\end{array}$ \\
\hline Was ever elected to public office & 0.00 & $\begin{array}{c}0.36 \\
(0.50)\end{array}$ & $\begin{array}{c}0.18 \\
(0.39)\end{array}$ \\
\hline Overall interest in politics $(1=\min , 4=\max )$ & $\begin{array}{c}3.82 \\
(0.40)\end{array}$ & $\begin{array}{c}3.82 \\
(0.40)\end{array}$ & $\begin{array}{c}3.82 \\
(0.39)\end{array}$ \\
\hline Follows politics on TV $(1=\min , 3=\max )$ & $\begin{array}{c}1.82 \\
(0.60)\end{array}$ & $\begin{array}{c}2.91 \\
(0.30)\end{array}$ & $\begin{array}{c}2.36 \\
(0.73)\end{array}$ \\
\hline Follows politics on radio $(1=\min , 3=\max )$ & $\begin{array}{c}1.45 \\
(0.52)\end{array}$ & $\begin{array}{c}1.82 \\
(0.75)\end{array}$ & $\begin{array}{c}1.64 \\
(0.66)\end{array}$ \\
\hline Follows politics on newspapers $(1=\min , 3=\max )$ & $\begin{array}{c}2.36 \\
(0.67)\end{array}$ & $\begin{array}{c}2.73 \\
(0.47)\end{array}$ & $\begin{array}{c}2.55 \\
(0.60)\end{array}$ \\
\hline Follows politics on the internet $(1=\min , 3=\max )$ & $\begin{array}{c}2.64 \\
(0.67)\end{array}$ & $\begin{array}{c}2.36 \\
(0.50)\end{array}$ & $\begin{array}{c}2.50 \\
(0.60)\end{array}$ \\
\hline Summary index of political engagement/awareness & $\begin{array}{l}-0.196 \\
(0.328)\end{array}$ & $\begin{array}{c}0.196 \\
(0.243)\end{array}$ & $\begin{array}{l}-0.000 \\
(0.346)\end{array}$ \\
\hline Sample size & 11 & 11 & 22 \\
\hline
\end{tabular}

Notes: The table reports means and standard deviations in parentheses of survey variables. 
Table 2: Covariate Balance: Voters' Characteristics

\begin{tabular}{|c|c|c|c|c|}
\hline & \multirow[b]{2}{*}{$\begin{array}{c}\text { Control } \\
\text { (1) }\end{array}$} & \multicolumn{3}{|c|}{ Treatment - Control Difference } \\
\hline & & $\begin{array}{l}\text { Assigned to } \\
\text { Volunteers } \\
\text { (2) }\end{array}$ & $\begin{array}{l}\text { Assigned to } \\
\text { Candidates } \\
\text { (3) }\end{array}$ & $\begin{array}{c}\text { Any } \\
\text { Treatment } \\
(4)\end{array}$ \\
\hline Age & $\begin{array}{c}55.23 \\
(18.75)\end{array}$ & $\begin{array}{c}0.04 \\
(0.37)\end{array}$ & $\begin{array}{c}0.53 \\
(0.35)\end{array}$ & $\begin{array}{c}0.28 \\
(0.30)\end{array}$ \\
\hline Female & $\begin{array}{c}0.524 \\
(0.499)\end{array}$ & $\begin{array}{c}0.004 \\
(0.005)\end{array}$ & $\begin{array}{c}0.009 \\
(0.005)\end{array}$ & $\begin{array}{c}0.006 \\
(0.004)\end{array}$ \\
\hline Married female & $\begin{array}{c}0.262 \\
(0.440)\end{array}$ & $\begin{array}{c}0.010 \\
(0.005)\end{array}$ & $\begin{array}{c}0.009 \\
(0.005)\end{array}$ & $\begin{array}{c}0.009 \\
(0.004)\end{array}$ \\
\hline Widow & $\begin{array}{c}0.088 \\
(0.284)\end{array}$ & $\begin{array}{l}-0.003 \\
(0.005)\end{array}$ & $\begin{array}{c}0.004 \\
(0.004)\end{array}$ & $\begin{array}{c}0.000 \\
(0.004)\end{array}$ \\
\hline Married male or widower & $\begin{array}{c}0.276 \\
(0.447)\end{array}$ & $\begin{array}{c}0.003 \\
(0.005)\end{array}$ & $\begin{array}{c}0.003 \\
(0.005)\end{array}$ & $\begin{array}{c}0.003 \\
(0.004)\end{array}$ \\
\hline Born in the province & $\begin{array}{c}0.639 \\
(0.480)\end{array}$ & $\begin{array}{c}0.009 \\
(0.009)\end{array}$ & $\begin{array}{c}0.001 \\
(0.009)\end{array}$ & $\begin{array}{c}0.005 \\
(0.007)\end{array}$ \\
\hline Born abroad & $\begin{array}{c}0.032 \\
(0.175)\end{array}$ & $\begin{array}{c}0.001 \\
(0.003)\end{array}$ & $\begin{array}{c}0.004 \\
(0.003)\end{array}$ & $\begin{array}{c}0.002 \\
(0.002)\end{array}$ \\
\hline Number of voters in building & $\begin{array}{c}19.72 \\
(13.34)\end{array}$ & $\begin{array}{l}-0.18 \\
(0.85)\end{array}$ & $\begin{array}{c}0.39 \\
(0.82)\end{array}$ & $\begin{array}{c}0.09 \\
(0.68)\end{array}$ \\
\hline Did not vote in 2013 & $\begin{array}{c}0.133 \\
(0.339)\end{array}$ & $\begin{array}{l}-0.003 \\
(0.006)\end{array}$ & $\begin{array}{c}0.0003 \\
(0.0061)\end{array}$ & $\begin{array}{l}-0.001 \\
(0.005)\end{array}$ \\
\hline Voted in 2013 & $\begin{array}{c}0.807 \\
(0.395)\end{array}$ & $\begin{array}{c}0.003 \\
(0.008)\end{array}$ & $\begin{array}{c}0.006 \\
(0.007)\end{array}$ & $\begin{array}{c}0.004 \\
(0.006)\end{array}$ \\
\hline Not in the 2013 voter rolls & $\begin{array}{c}0.060 \\
(0.238)\end{array}$ & $\begin{array}{l}-0.0002 \\
(0.0046)\end{array}$ & $\begin{array}{l}-0.007 \\
(0.004)\end{array}$ & $\begin{array}{l}-0.003 \\
(0.004)\end{array}$ \\
\hline $\begin{array}{l}\text { F-test } \\
p \text {-value }\end{array}$ & & $\begin{array}{c}0.86 \\
0.567\end{array}$ & $\begin{array}{c}1.23 \\
0.264\end{array}$ & $\begin{array}{c}1.12 \\
0.342\end{array}$ \\
\hline Sample size & 13,181 & 19,855 & 19,678 & 26,352 \\
\hline
\end{tabular}

Notes: Each of the 26,352 voters in the sample resides in one of 2,612

addresses/buildings: 1,323 assigned to the control group, and 642 (647) assigned to be canvassed by volunteers (candidates). The sample size of column 2 (3) includes 13,181 control group voters and $6,674(6,497)$ voters assigned to be canvassed by volunteers (candidates). The sample size of column 3 refers to all voters subject to randomization. Treatment-control differences are from regressions that control for strata (street name by precinct) dummies. Standard errors are clustered at the residential address level.

$* * \mathrm{p}<0.01, * \mathrm{p}<0.05, \sim \mathrm{p}<0.10$ 
Table 3: Covariate Balance: Canvassers' Political Engagement and Canvassed Voters' Characteristics

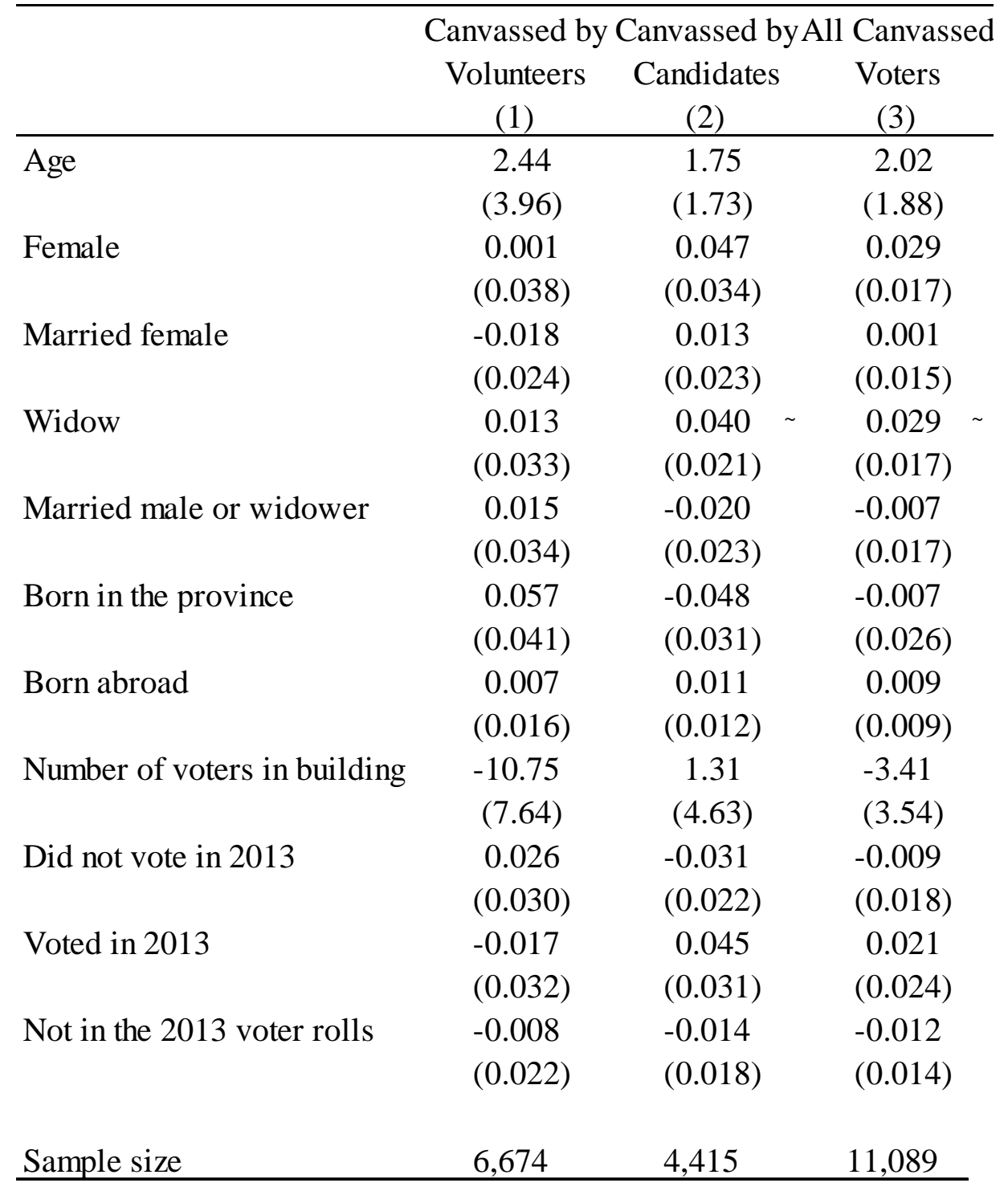

Notes: Each cell reports estimates from a regression of the row variable, which represents a voter characteristic, on the political engagement index of the visiting canvassers. The samples in columns 1 and 2 are voters whose addresses were visited by party volunteers and candidates, respectively. Regressions in column 3 are run on all voters living in canvassed addresses, and include dummies for whether the address was visited by volunteers or candidates. Standard errors are clustered at the precinct level.

$* * \mathrm{p}<0.01, * \mathrm{p}<0.05, \sim \mathrm{p}<0.10$ 
Table 4: Treatment Effects on Voter Turnout: Main Results

\begin{tabular}{lcc}
\hline & \multicolumn{2}{c}{ Turnout } \\
& $(1)$ & $(2)$ \\
\hline Canvassed by volunteers & $0.018^{*}$ & 0.014 \\
& $(0.008)$ & $(0.006)$ \\
Canvassed by candidates & -0.002 & -0.005 \\
& $(0.012)$ & $(0.010)$ \\
Age & & 0.0006
\end{tabular}${ }^{* *}$

Notes: All regressions control for strata dummies. Due to the incomplete delivery of the candidate treatment, the "Canvassed by candidates" regressor is instrumented by a dummy equal to 1 if the address was assigned to be canvassed by candidates. The omitted category for voter turnout in 2013 is "Not in the 2013 voter rolls". Standard errors are clustered at the residential address level.

$* * \mathrm{p}<0.01, * \mathrm{p}<0.05, \sim \mathrm{p}_{29}<0.10$ 
Table 5: Treatment Effects on Voter Turnout by Voter Characteristics

\begin{tabular}{|c|c|c|c|}
\hline & \multirow{2}{*}{$\begin{array}{c}\text { Control } \\
\text { Mean } \\
\text { (1) }\end{array}$} & \multicolumn{2}{|c|}{ Treatment Effects } \\
\hline & & $\begin{array}{l}\text { Volunteers } \\
\text { (2) }\end{array}$ & $\begin{array}{c}\text { Candidates } \\
\text { (3) }\end{array}$ \\
\hline \multirow[t]{2}{*}{ Average effect } & 0.747 & $\begin{array}{c}0.014 \\
(0.006)\end{array}$ & $\begin{array}{l}-0.005 \\
(0.010)\end{array}$ \\
\hline & \multicolumn{3}{|c|}{ Interactions with 2013 Turnout } \\
\hline Did not vote in 2013 & 0.249 & $\begin{array}{c}0.003 \\
(0.020)\end{array}$ & $\begin{array}{c}0.024 \\
(0.028)\end{array}$ \\
\hline Voted in 2013 & 0.840 & $\begin{array}{c}0.0166^{*} \\
(0.006)\end{array}$ & $\begin{array}{l}-0.012 \\
(0.011)\end{array}$ \\
\hline Not in the 2013 voter rolls & 0.604 & $\begin{array}{c}0.013 \\
(0.034)\end{array}$ & $\begin{array}{c}0.030 \\
(0.052)\end{array}$ \\
\hline Sample size & 13,181 & 26,352 & 26,352 \\
\hline
\end{tabular}

Notes: The table reports results from a pooled regression that distinguishes the effects of the volunteer (column 2) and candidate visits (column 3 ) on the set of voters defined by the row variable, along with the estimates from column 2 of Table 4 . All regressions control for strata dummies and the same set of baseline covariates reported in Table 4, column 2. Interactions between voters' characteristics and the candidate treatment are instrumented by interactions between the same voter characteristics and a dummy for whether the voters' address was assigned to be canvassed by candidates. Standard errors are clustered at the residential address level.

$* * \mathrm{p}<0.01, * \mathrm{p}<0.05, \sim \mathrm{p}<0.10$ 
Table 6: Treatment Effects on Voter Turnout by Canvassers' Political Competence

\begin{tabular}{lcc}
\hline & \multicolumn{2}{c}{ Turnout } \\
\hline Canvassed by volunteers & 0.018 & $(2)$ \\
& $(0.009)$ & $0.014 \sim$ \\
& {$[0.057]$} & {$[0.008)$} \\
& $\{0.080\}$ & $\{0.099\}$ \\
Canvassed by candidates & -0.003 & -0.005 \\
& $(0.011)$ & $(0.010)$ \\
Canvassed by volunteers*z-score & {$[0.779]$} & {$[0.605]$} \\
& $\{0.763\}$ & $\{0.590\}$ \\
Canvassed by candidates*z-score & $(0.043)$ & -0.076 \\
& {$[0.113]$} & {$[0.037)$} \\
& $\{0.155\}$ & $\{0.041]$ \\
& 0.034 & $0.021\}$ \\
Sample size & $(0.036)$ & $(0.029)$ \\
& {$[0.336]$} & {$[0.478]$} \\
Noter & $\{0.308\}$ & $\{0.470\}$ \\
& & yes \\
& 26,352 & 26,352 \\
\hline
\end{tabular}

Notes: The table reports estimates and precinct-clustered standard errors in parentheses from regressions of voter turnout on the two treatment dummies, their interactions with the canvassers' index of political competence, and strata dummies. Column 2's regression also controls for the covariates reported in Table 4, column 2. "Canvassed by candidates" is instrumented with a dummy for assignment to the candidate treatment. Z-scores are demeaned by treatment. Precinct-clustered p-values are reported in parentheses and brackets. Bootstrap p-values clustered by precinct and by each of the two canvassers (if any) are reported in braces. Bootstrap p-values are based on Webb weights and 999 repetitions, a number chosen following Davidson and MacKinnon (2000) to ensure that the significance level times the sum of the number of bootstraps and one is an integer. Bootstrap p-values are computed using Stata boottest routine (Roodman et al., 2018).

** $\mathrm{p}<0.01, * \mathrm{p}<0.05, \sim \mathrm{p}<0.10$ 
Table 7: Treatment Effect on the List Vote Share

\begin{tabular}{lcccc}
\hline & \multicolumn{4}{c}{ List Vote Share } \\
& $(1)$ & $(2)$ & $(3)$ & $(4)$ \\
\hline Precinct canvassed by candidates & -0.0034 & -0.0029 & -0.0034 & -0.0027 \\
& $(0.0055)$ & $(0.0057)$ & $(0.0068)$ & $(0.0071)$ \\
& & yes & & yes \\
Weighted by \# of voters in precinct & & & yes & yes \\
Precinct covariates & 0.0341 & 0.0348 & 0.0341 & 0.0348 \\
Mean dep. var. & 38 & 38 & 38 & 38 \\
Sample size &
\end{tabular}

Notes: Each column reports coefficients and standard errors from a regression of the civic list's vote share at the precinct level on a dummy for whether the precinct received the visits of candidates. 25 of the 38 precincts in the sample received the visits of candidates.

Regressions in columns 2 and 4 are weighted by the number of eligible voters in the precinct. Regressions in columns 3 and 4 also control for precinct averages of the covariates reported in column 2 of Table 4 . Robust standard errors are obtained using the HC3 small-sample adjustment.

$* * \mathrm{p}<0.01, * \mathrm{p}<0.05, \sim \mathrm{p}<0.10$ 
Table 8: Treatment Effects on Candidates' Votes Received

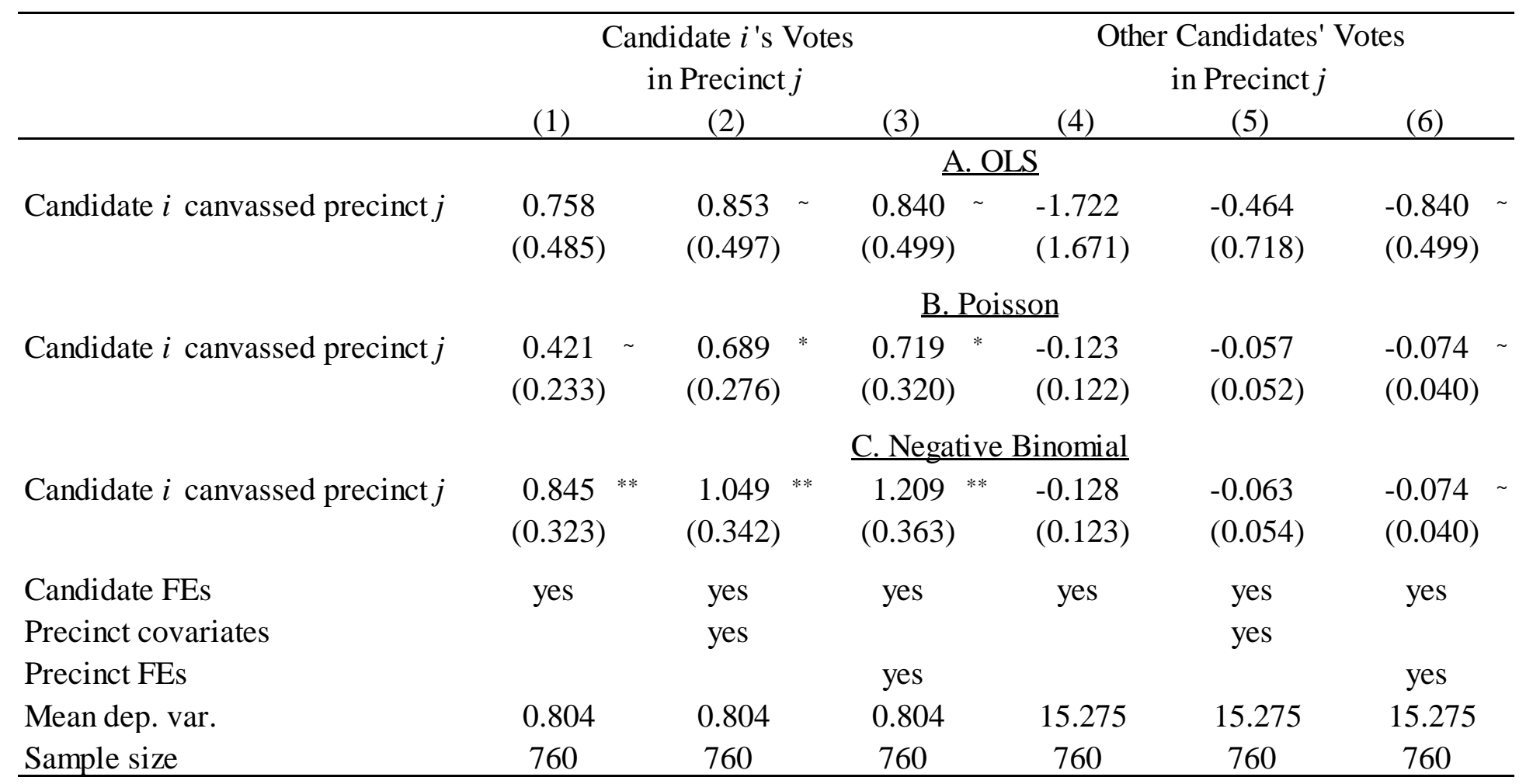

Notes: The sample consists of the 20 civic list's candidates times the 38 precincts included in the experiment. The treatment is a dummy for whether the candidate was randomly assigned to canvass a certain precinct. The dependent variable in columns 1-3 (4-6) is the number of preferences the candidate herself/himself (all candidates but oneself) received in the precinct. Standard errors are clustered at the precinct level.

$* * \mathrm{p}<0.01, * \mathrm{p}<0.05, \sim \mathrm{p}<0.10$ 


\section{References}

Arceneaux, K. (2007). I'm Asking for Your Support: The Effects of Personally Delivered Campaign Messages on Voting Decisions and Opinion Formation. Quarterly Journal of Political Science 2(1), 43-65.

Arceneaux, K. and D. W. Nickerson (2009). Who is Mobilized to Vote? A Re-Analysis of Eleven Randomized Field Experiments. American Journal of Political Science 53(1), 1-16.

Arceneaux, K. and D. W. Nickerson (2010). Comparing Negative and Positive Campaign Messages: Evidence From Two Field Experiments. American Politics Research 38(1), 54-83.

Ashworth, S. (2006). Campaign finance and voter welfare with entrenched incumbents. American Political Science Review 100(01), 55-68.

Atkeson, L. R. (1999). Sure, I Voted for the Winner! Overreport of the Primary Vote for the Party Nominee in the National Election Studies. Political Behavior 21(3), 197-215.

Bailey, M., D. J. Hopkins, and T. Rogers (2014, may). Unresponsive and Unpersuaded: The Unintended Consequences of Voter Persuasion Efforts. Available at SSRN 2307631.

Ballini, P. L. and M. Ridolfi (2002). Storia delle campagne elettorali in Italia. 1, 302.

Barton, J., M. Castillo, and R. Petrie (2014). What Persuades Voters? A Field Experiment on Political Campaigning. The Economic Journal 124(574), 293-326.

Bhatti, Y., J. O. Dahlgaard, J. Hedegaard Hansen, and K. M. Hansen (2018). Is Door-to-Door Canvassing Effective in Europe? Evidence from a Meta-study across Six European Countries. British Journal of Political Science Forthcoming.

Bhatti, Y., E. Fieldhouse, and K. M. Hansen (2018, Jul). It's a group thing: How voters go to the polls together. Political Behavior.

Blais, A. (2010). Political participation. Comparing democracies 3, 165-183. 
Blais, A. and D. Rubenson (2013). The source of Turnout Decline: New Values or New contexts? Comparative Political Studies 46(1), 95-117.

Blom-Hansen, J., J. Elklit, S. Serritzlew, and L. R. Villadsen (2016). Ballot position and election results: Evidence from a natural experiment. Electoral Studies 44, 172 - 183.

Brady, H., S. Verba, and K. L. Schlozman (1995). Voice and equality: Civic voluntarism in American politics. Cambridge: Harvard University Press.

Cameron, C. A. and P. K. Trivedi (2013). Regression Analysis of Count Data (2nd ed.). Cambridge: Cambridge University Press.

Campbell, J. E. (2010, oct). The Seats in Trouble Forecast of the 2010 Elections to the U.S. House. PS: Political Science \& Politics 43(04), 627-630.

Cardy, E. A. (2005, sep). An Experimental Field Study of the GOTV and Persuasion Effects of Partisan Direct Mail and Phone Calls. The Annals of the American Academy of Political and Social Science 601(1), 28-40.

Cox, G. W. (1997). Making Votes Count: Strategic Coordination in the World's Electoral Systems. Cambridge: Cambridge University Press.

Dalton, R. J. (2007). The Good Citizen: How a Younger Generation is Reshaping American Politics. Washington: Congressional Quarterly Press.

DellaVigna, S. and M. Gentzkow (2010). Persuasion: Empirical Evidence. Annual Review of Economics 2, 643-649.

Duverger, M. (1954). Political Parties: Their Organization and Activity in the Modern State. New York: Wiley.

ECPRD (2000). The ECPRD: Electoral Systems in Europe: an Overview. European Centre for Parliamentary Research and Documentation. 
Enos, R. D., A. Fowler, and L. Vavreck (2014). Increasing Inequality: The Effect of GOTV Mobilization on the Composition of the Electorate. The Journal of Politics 76(1), 273-288.

Enos, R. D. and E. D. Hersh (2015). Party Activists as Campaign Advertisers: The Ground Campaign as a Principal-Agent Problem. The American Political Science Review 109(2), 252-278.

Foos, F. and P. John (2018). Parties are No Civic Charities: Voter Contact and the Changing Partisan Composition of the Electorate. Political Science Research and Methods 6(2), 283-298.

Franklin, M. N., P. Lyons, and M. Marsh (2004). Generational Basis of Turnout Decline in Established Democracies. Acta Politica 39(2), 115-151.

Galasso, V. and T. Nannicini (2018). Persuasion and Gender: Experimental Evidence from Two Political Campaigns.

Gelman, A., S. Goel, D. Rivers, and D. Rothschild (2016). The Mythical Swing Voter. Quarterly Journal of Political Science 11(1), 103-130.

Gerber, A. S. and D. P. Green (2000). The Effects of Canvassing on Voter Turnout. American Political Science Review 94(3), 653-663.

Gerber, A. S. and D. P. Green (2017). Field experiments on voter mobilization: An overview of a burgeoning literature. In A. V. Banerjee and E. Duflo (Eds.), Handbook of Economic Field Experiments, Volume 1, Chapter 9, pp. 395-438. Elsevier.

Gerber, A. S., D. P. Green, and M. Green (2003, dec). Partisan mail and voter turnout: results from randomized field experiments. Electoral Studies 22(4), 563-579.

Gosnell, H. F. (1930). Why Europe Votes. The University of Chicago Press.

Gray, M. and M. Caul (2000). Declining Voter Turnout in Advanced Industrial Democracies, 1950 to 1997: The effects of declining group mobilization. Comparative Political Studies 33(9), $1091-1122$. 
Green, D. P. and A. S. Gerber (2015). Get Out the Vote: How to Increase Voter Turnout. Brookings Institution Press.

Green, D. P., A. S. Gerber, and D. W. Nickerson (2003). Getting Out the Vote in Local Elections: Results from Six Door-to-Door Canvassing Experiments. Journal of Politics 65(4), 1083-1096.

Green, D. P., M. C. McGrath, and P. M. Aronow (2013a). Field Experiments and the Study of Voter Turnout. Journal of Elections, Public Opinion and Parties 23(1), 27-48.

Green, D. P., M. C. McGrath, and P. M. Aronow (2013b). Field experiments and the study of voter turnout. Journal of Elections, Public Opinion and Parties 23(1), 27-48.

Hoffman, E., K. McCabe, and V. Smith (1996). Social distance and other-regarding behavior in dictator games. The American Economic Review 86(3), 653-660.

John, P. and T. Brannan (2008). How Different Are Telephoning and Canvassing? Results from a 'Get Out the Vote' Field Experiment in the British 2005 General Election. British Journal of Political Science 38(03), 565-574.

Johnston, R., S. J. Matthews, and A. Bittner (2006). Alienation, indifference, competitiveness, and turnout: Evidence from Canada. Electoral Studies 26(4), 735-745.

Kling, J. R., J. B. Liebman, and L. F. Katz (2007). Experimental Analysis of Neighborhood Effects. Econometrica 75(1), 83-119.

Landry, C. E., A. Lange, J. A. List, M. K. Price, and N. G. Rupp (2006). Toward an Understanding of the Economics of Charity: Evidence From a Field Experiment. Quarterly Journal of Economics 121(2), 747-782.

Liegey, G., A. Muller, and V. Pons (2013). Porte-à-Porte: Reconquérir la démocratie sur le terrain. Calmann-Lévy.

Lijphart, A. (1997). Unequal Participation: Democracy's Unresolved Dilemma. The American Political Science Review 91(1), 1-14. 
Michelson, M. R. (2005). Meeting the Challenge of Latino Voter Mobilization. The Annals of the American Academy of Political and Social Science of the American Academy of Political and Social Science 601(1), 85-101.

Nickerson, D. W. (2007). Quality is job one: Professional and volunteer voter mobilization calls. American Journal of Political Science 51(2), 269-282.

Nickerson, D. W., R. D. Friedrichs, and D. C. King (2006). Partisan Mobilization Campaigns in the Field: Results from a Statewide Turnout Experiment in Michigan. Political Research Quarterly 59(1), 85-97.

Novelli, E. (2018). Le campagne elettorali in Italia.

Nyman, P. (2017). Door-to-door canvassing in the European elections: Evidence from a Swedish field experiment. Electoral Studies 45(1), 110-118.

Pons, V. (2018). Will a Five-Minute Discussion Change your Mind? A Countrywide Experiment on Voter Choice in France. American Economic Review 108(6), 1322-1363.

Pons, V. and G. Liegey (2019). Increasing the Electoral Participation of Immigrants: Experiment Evidence from France. The Economic Journal 129(617), 481-508.

Potters, J., R. Sloof, and F. van Winden (1997, feb). Campaign expenditures, contributions and direct endorsements: The strategic use of information and money to influence voter behavior. European Journal of Political Economy 13(1), 1-31.

Price, M. K. (2008). Fund-raising success and a solicitor's beauty capital: Do blondes raise more funds? Economics Letters 100, 351-354.

Putnam, R. D. and S. J. Pharr (2000). Disaffected democracies: What's troubling the trilateral countries? Princeton University Press.

Radcliff, B. (1992). The Welfare State, Turnout, and the Economy: A Comparative Analysis. American Political Science Review 86(02), 444-454. 
Sinclair, B., M. Mcconnell, and M. R. Michelson (2007). Strangers vs. Neighbors: The Efficacy of Grassroots Voter Mobilization. Annual meeting of the American Political Science Association.

Solijonov, A. (2016). Voter Turnout Trends around the World. Technical report, International Institute for Democracy and Electoral Assistance (International IDEA), Stockholm.

Taylor, S. L., M. S. Shugart, A. Lijphart, and B. Grofman (2014). A Different Democracy: American Government in a 31-Country Perspective. New Haven \& London: Yale University Press.

Teixeira, R. A. (1992). The Disappearing Voter. Washington, DC: Brookings Institution.

Verba, S. and N. H. Nie (1972). Participation in America: Political democracy and social equality. New York: Harper and Row.

Wantchekon, L. (2003). Clientelism and voting behavior: Evidence from a field experiment in Benin. World politics 55(03), 399-422.

Wattenberg, M. P. (2002). Where have all the voters gone? Harvard University Press.

Wolfinger, R. E. and S. J. Rosenstone (1980). Who votes? New Haven: Yale University Press.

Wright, G. C. (1993). Errors in Measuring Vote Choice in the National Election Studies, 1952-88. American Journal of Political Science 37, 291-316. 


\section{A APPENDIX (FOR ONLINE-ONLY PUBLICATION)}

\section{A.1 2SLS Regressions With Endogenous Door-Opening-Rates}

Regressions in the paper do not correct for whether a voter was actually contacted by canvassers. Following the literature (e.g., Gerber and Green, 2000), it is only in a second step that we relate regression estimates to the fraction of opened doors to estimate what fraction of contacted voters were successfully persuaded. Here, we present the results obtained with an alternative approach. We use a just-identified 2SLS framework, and instrument the fraction of opened doors in building $b$ assigned to treatment $t$, \%doors ${ }_{b(i)}^{t}$, with a dummy for assignment to treatment $t$. Formally, in lieu of equation 2, we estimate the following regression:

$$
\text { Vote }_{i}=\alpha+\sum_{k} \theta^{v, k} Z_{i}^{k} \times \% \operatorname{doors}_{b(i)}^{v}+\sum_{k} \theta^{c, k} Z_{i}^{k} \times \% \operatorname{doors}_{b(i)}^{c}+X_{i, b(i)}^{\prime} \lambda+\sum_{s} \delta_{b(i)}^{s}+\varepsilon_{i}
$$

where $Z_{i}^{k} \times \%$ doors $s_{b(i)}^{t}$ is instrumented by $Z_{i}^{k} \times \mathbf{1}(b(i)$ assigned to treatment $t)$. Consistently with the results of Table 5, 2SLS estimates in Table A.1 suggest that the impact of volunteers' visits is significant and larger for voters with a higher-than-average propensity to vote. Conversely, candidates' visits did not have any significant impact on turnout for any type of voter. 
Table A.1: Treatment Effects on Voter Turnout by Voter Characteristics: Instrumenting for DoorOpening Rates

\begin{tabular}{|c|c|c|c|}
\hline & \multirow{2}{*}{$\begin{array}{c}\text { Control } \\
\text { Mean } \\
\text { (1) }\end{array}$} & \multicolumn{2}{|c|}{ Treatment Effects } \\
\hline & & $\begin{array}{c}\text { Volunteers } \\
(2) \\
\end{array}$ & $\begin{array}{c}\text { Candidates } \\
(3) \\
\end{array}$ \\
\hline \multirow[t]{2}{*}{ Average effect } & 0.747 & $\begin{array}{l}0.0411^{*} \\
(0.018)\end{array}$ & $\begin{array}{l}-0.011 \\
(0.023)\end{array}$ \\
\hline & \multicolumn{3}{|c|}{ A. Interactions with 2013 Turnout } \\
\hline Did not vote in 2013 & 0.249 & $\begin{array}{c}0.008 \\
(0.057)\end{array}$ & $\begin{array}{c}0.056 \\
(0.065)\end{array}$ \\
\hline Voted in 2013 & 0.840 & $\begin{array}{c}0.046 * \\
(0.018)\end{array}$ & $\begin{array}{l}-0.027 \\
(0.024)\end{array}$ \\
\hline \multirow[t]{2}{*}{ Not in the 2013 voter rolls } & 0.604 & $\begin{array}{c}0.040 \\
(0.103)\end{array}$ & $\begin{array}{c}0.070 \\
(0.120)\end{array}$ \\
\hline & \multicolumn{3}{|c|}{ B. Interactions with Gender } \\
\hline Male & 0.757 & $\begin{array}{c}0.043 * \\
(0.022)\end{array}$ & $\begin{array}{l}-0.013 \\
(0.029)\end{array}$ \\
\hline \multirow[t]{2}{*}{ Female } & 0.738 & $\begin{array}{c}0.040 \sim \\
(0.022)\end{array}$ & $\begin{array}{l}-0.008 \\
(0.027)\end{array}$ \\
\hline & \multicolumn{3}{|c|}{$\underline{\text { C. Interactions with Place of Birth }}$} \\
\hline Born in the province & 0.776 & $\begin{array}{c}0.062^{* *} \\
(0.021)\end{array}$ & $\begin{array}{c}0.002 \\
(0.026)\end{array}$ \\
\hline Born elsewhere in the region & 0.738 & $\begin{array}{c}0.060 \\
(0.055)\end{array}$ & $\begin{array}{c}0.036 \\
(0.061)\end{array}$ \\
\hline \multirow[t]{2}{*}{ Born out of the region } & 0.684 & $\begin{array}{l}-0.013 \\
(0.038)\end{array}$ & $\begin{array}{l}-0.056 \\
(0.045)\end{array}$ \\
\hline & \multicolumn{3}{|c|}{ D. Interactions with Age } \\
\hline Main treatment effect & & $\begin{array}{c}0.095 * \\
(0.045)\end{array}$ & $\begin{array}{l}-0.002 \\
(0.054)\end{array}$ \\
\hline Age*treatment & & $\begin{array}{l}-0.001 \\
(0.001)\end{array}$ & $\begin{array}{l}-0.0002 \\
(0.0012)\end{array}$ \\
\hline Sample size & 13,181 & 26,352 & 26,352 \\
\hline
\end{tabular}

Notes: Panels A-C report results from pooled 2SLS regressions that distinguish the effects of the volunteer (column 2) and candidate visits (column 3) on the set of voters defined by the row variable. For each treatment, the endogenous variables are the interactions between the fraction of open doors in the building and the voter characteristics in rows. The corresponding instruments are the interactions between the treatment assignment dummy and the same set of voter characteristics. All regressions control for strata dummies and the same set of baseline covariates reported in Table 4, column 2. Standard errors are clustered at the residential address level.

$* * \mathrm{p}<0.01, * \mathrm{p}<0.05, \sim \mathrm{p}<0.10^{41}$ 


\section{A.2 Interactions with Canvassers' Political Competence: Robustness Checks}

Table A.2 reports estimates from regression 3 under alternative measures of canvassers' political competence. Columns 1 and 2 correspond to the estimates of Table 6, where indices of canvassers' political competence are constructed using all survey information reported in Panel B of Table 1. The z-score used for regressions in columns 3 and 4 (5 and 6) is constructed using (excluding) only the following responses: "Voted in 2013 national elections", "Voted in last municipal election", and "Was ever elected to public office". The z-score in columns 7 and 8 includes all survey responses from Table 1, Panel B, but "Was ever elected to public office".

With the exception of columns 3 and 4, interaction coefficients are substantively unaffected by the choice of the canvassers' political competence index. One explanation of this exception is that past turnout might be a surprisingly misleading proxy for the volunteers' political engagement. For reasons of college enrollment, in fact, most volunteers resided in regions different than the one of voter registration, making it perhaps prohibitively costly for them to vote ${ }^{27}$ independently of their actual level of interest in politics.

\footnotetext{
${ }^{27}$ There is no absentee voting in Italy.
} 
Table A.2: Treatment Effects on Voter Turnout by Canvassers' Political Competence: Robustness Checks

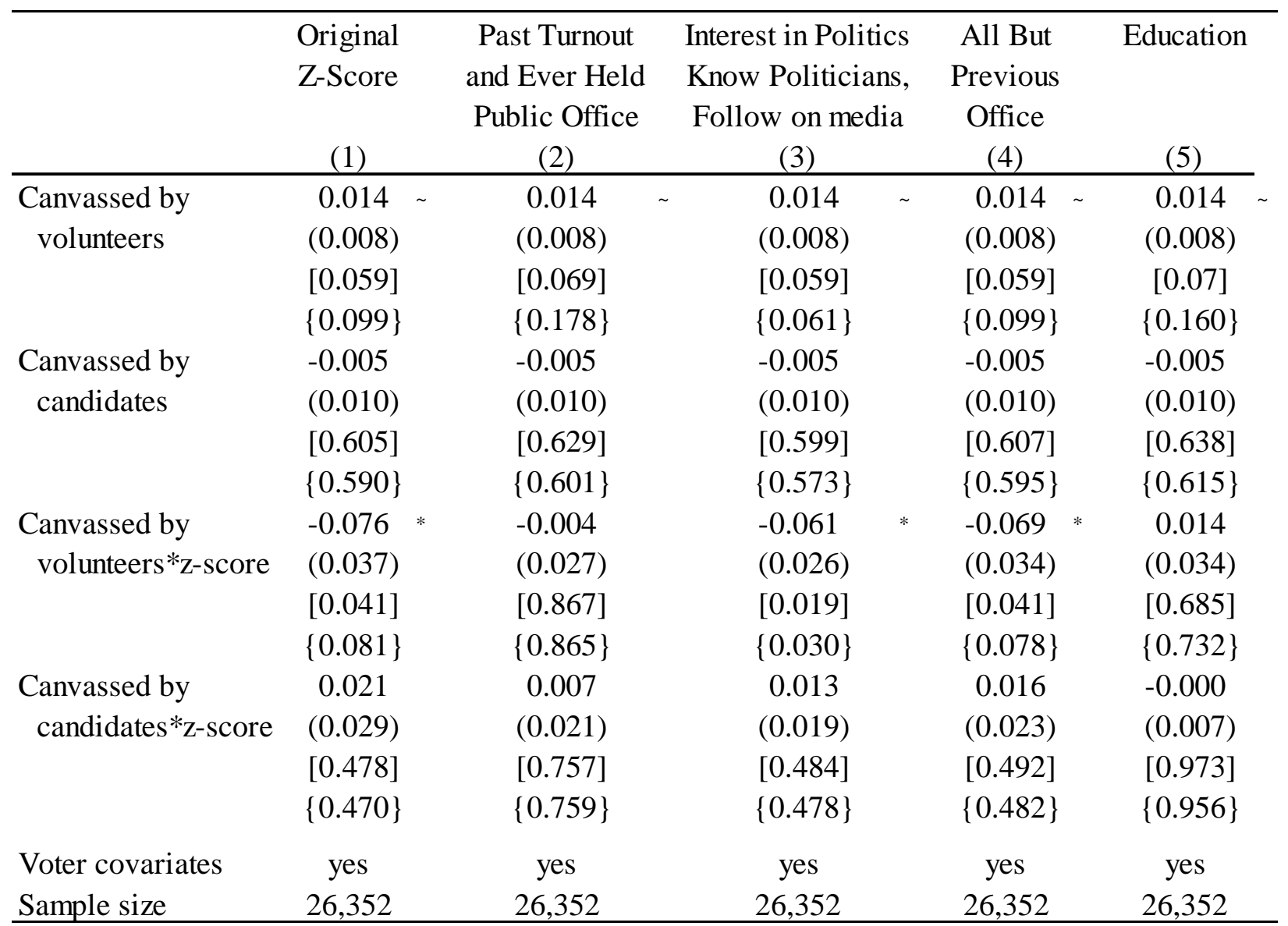

Notes: Columns 1 reports the same estimates of Table 6, column 2. Columns 2-5 verify the robustness of the interactions with canvassers' z-scores to alternative definitions of the political competence index. The z-score for column 2 (resp. 3) is the sum of (resp. all but) the z-scores of the following variables from Table 1, Panel B: "Voted in 2013 national elections", "Voted in last municipal election", and "Was ever elected to public office". The z-score for column 4 is the sum of the z-scores of all variables except "Was ever elected to public office". The z-score for column 5 is the z-score of the "Education" variable reported in Panel A of Table 1. Standard errors and p-values clustered at the precinct level are reported in parentheses and brackets, respectively. Wild bootstrap p-values, robust to three-way clustering by precinct and by each of the two canvassers (if any) who canvassed a given address, are reported in braces. See notes to Table 6 for details on the bootstrap procedure.

$* * \mathrm{p}<0.01, * \mathrm{p}<0.05, \sim \mathrm{p}<0.10$ 
A.3 Additional Balancing Exercises and Robustness Checks 
Table A.3: Canvassers' Political Engagement and Canvassed Voters' Characteristics Covariate Balance: Precinct-Clustered vs. Wild-Bootstrap P-Values

\begin{tabular}{|c|c|c|c|}
\hline & \multicolumn{3}{|c|}{ Canvassed by Canvassed by All Canvass } \\
\hline & $\begin{array}{c}\text { Volunteers } \\
(1)\end{array}$ & $\begin{array}{c}\text { Candidates } \\
(2) \\
\end{array}$ & $\begin{array}{c}\text { Voters } \\
(3) \\
\end{array}$ \\
\hline \multirow[t]{3}{*}{ Age } & 2.44 & 1.75 & 2.02 \\
\hline & {$[0.542]$} & {$[0.321]$} & {$[0.290]$} \\
\hline & $\{0.676\}$ & $\{0.619\}$ & $\{0.374\}$ \\
\hline \multirow[t]{3}{*}{ Female } & 0.001 & 0.047 & 0.029 \\
\hline & {$[0.986]$} & {$[0.184]$} & {$[0.101]$} \\
\hline & $\{0.978\}$ & $\{0.659\}$ & $\{0.118\}$ \\
\hline \multirow[t]{3}{*}{ Married female } & -0.018 & 0.013 & 0.001 \\
\hline & {$[0.457]$} & {$[0.581]$} & [0.949] \\
\hline & $\{0.499\}$ & $\{0.639\}$ & $\{0.951\}$ \\
\hline \multirow[t]{3}{*}{ Widow } & 0.013 & 0.040 & 0.029 \\
\hline & {$[0.697]$} & {$[0.063]$} & {$[0.092]$} \\
\hline & $\{0.868\}$ & $\{0.229\}$ & $\{0.323\}$ \\
\hline \multirow[t]{3}{*}{ Married male or widower } & 0.015 & -0.020 & -0.007 \\
\hline & {$[0.666]$} & {$[0.381]$} & {$[0.691]$} \\
\hline & $\{0.709\}$ & $\{0.551\}$ & $\{0.763\}$ \\
\hline \multirow[t]{3}{*}{ Born in the province } & 0.057 & -0.048 & -0.007 \\
\hline & {$[0.167]$} & {$[0.131]$} & {$[0.792]$} \\
\hline & $\{0.276\}$ & $\{0.202\}$ & $\{0.802\}$ \\
\hline \multirow[t]{3}{*}{ Born abroad } & 0.007 & 0.011 & 0.009 \\
\hline & {$[0.661]$} & {$[0.360]$} & [0.289] \\
\hline & $\{0.596\}$ & $\{0.598\}$ & $\{0.396\}$ \\
\hline \multirow[t]{3}{*}{ Number of voters in building } & -10.75 & 1.31 & -3.41 \\
\hline & {$[0.17]$} & {$[0.78]$} & {$[0.34]$} \\
\hline & $\{0.54\}$ & $\{0.72\}$ & $\{0.50\}$ \\
\hline \multirow[t]{3}{*}{ Did not vote in 2013} & 0.026 & -0.031 & -0.009 \\
\hline & {$[0.400]$} & {$[0.170]$} & {$[0.621]$} \\
\hline & $\{0.496\}$ & $\{0.381\}$ & $\{0.708\}$ \\
\hline \multirow[t]{3}{*}{ Voted in 2013} & -0.017 & 0.045 & 0.021 \\
\hline & {$[0.592]$} & {$[0.160]$} & {$[0.397]$} \\
\hline & $\{0.554\}$ & $\{0.231\}$ & $\{0.418\}$ \\
\hline \multirow[t]{3}{*}{ Not in the 2013 voter rolls } & -0.008 & -0.014 & -0.012 \\
\hline & {$[0.700]$} & {$[0.441]$} & {$[0.406]$} \\
\hline & $\{0.363\}$ & $\{0.355\}$ & $\{0.145\}$ \\
\hline Sample size & 6,674 & 4,415 & 11,089 \\
\hline
\end{tabular}

Notes: This table reports the same point estimates as Table 3.

Precinct-clustered asymptotic p-values are reported in brackets. Wild bootstrap p-values, robust to three-way clustering by precinct and by each of the two canvassers (if any) who canvassed a given address, are reported in braces. See notes to Table 6 for details on the bootstrap procedure. 
Table A.4: Treatment Effects on Voter Turnout by Voter Gender, Place of Birth, and Age

\begin{tabular}{|c|c|c|c|c|}
\hline & \multirow{2}{*}{$\begin{array}{c}\text { Control } \\
\text { Mean } \\
(1)\end{array}$} & \multicolumn{3}{|c|}{ Treatment Effects } \\
\hline & & $\begin{array}{c}\text { Volunteers } \\
\text { (2) }\end{array}$ & & $\begin{array}{c}\text { Candidates } \\
\text { (3) }\end{array}$ \\
\hline \multirow[t]{2}{*}{ Average effect } & 0.747 & $\begin{array}{c}0.014 \\
(0.006)\end{array}$ & * & $\begin{array}{l}-0.005 \\
(0.010)\end{array}$ \\
\hline & \multicolumn{4}{|c|}{ A. Interactions with Gender } \\
\hline Male & 0.757 & $\begin{array}{c}0.015 \\
(0.008)\end{array}$ & * & $\begin{array}{l}-0.006 \\
(0.013)\end{array}$ \\
\hline \multirow[t]{2}{*}{ Female } & 0.738 & $\begin{array}{c}0.014 \\
(0.008)\end{array}$ & $\sim$ & $\begin{array}{l}-0.004 \\
(0.012)\end{array}$ \\
\hline & \multicolumn{4}{|c|}{ B. Interactions with Place of Birth } \\
\hline Born in the province & 0.776 & $\begin{array}{c}0.022 \\
(0.007)\end{array}$ & ** & $\begin{array}{c}0.001 \\
(0.012)\end{array}$ \\
\hline Born elsewhere in the region & 0.738 & $\begin{array}{c}0.022 \\
(0.020)\end{array}$ & & $\begin{array}{c}0.016 \\
(0.028)\end{array}$ \\
\hline \multirow[t]{2}{*}{ Born out of the region } & 0.684 & $\begin{array}{l}-0.005 \\
(0.013)\end{array}$ & & $\begin{array}{l}-0.025 \\
(0.020)\end{array}$ \\
\hline & \multicolumn{4}{|c|}{ C. Interactions with Age } \\
\hline Main treatment effect & & $\begin{array}{c}0.032 \\
(0.016)\end{array}$ & * & $\begin{array}{l}-0.001 \\
(0.024)\end{array}$ \\
\hline Age*treatment & & $\begin{array}{l}-0.0005 \\
(0.0004)\end{array}$ & & $\begin{array}{l}-0.0001 \\
(0.0005)\end{array}$ \\
\hline Sample size & 13,181 & 26,352 & & 26,352 \\
\hline
\end{tabular}

Notes: Each panel reports estimates from a separate regression. Panels A$B$ report results from pooled regressions that distinguish the effects of the volunteer (column 2) and candidate visits (column 3) on the set of voters defined by the row variable. All regressions control for strata dummies and the same set of baseline covariates reported in Table 4, column 2. Interactions between voters' characteristics and the candidate treatment are instrumented by interactions between the same voter characteristics and a dummy for whether the voters' address was assigned to be canvassed by candidates. Standard errors are clustered at the residential address level. $* * \mathrm{p}<0.01, * \mathrm{p}<0.05, \sim \mathrm{p}<0.10$ 
Table A.5: Precinct-Level Randomization Checks

\begin{tabular}{|c|c|c|c|}
\hline & \multirow[b]{2}{*}{$\begin{array}{c}\text { Control Mean } \\
\text { (1) }\end{array}$} & \multicolumn{2}{|c|}{ Treatment - Control Difference } \\
\hline & & $\begin{array}{l}\text { All Candidates } \\
\text { Sample } \\
(2)\end{array}$ & $\begin{array}{c}\text { Only Major } \\
\text { Candidates Sample } \\
\text { (3) }\end{array}$ \\
\hline Average age & $\begin{array}{l}55.57 \\
(3.04)\end{array}$ & $\begin{array}{cc}0.32 & \sim \\
(0.18) & \end{array}$ & $\begin{array}{c}0.38 \\
(0.22)\end{array}$ \\
\hline Share female & $\begin{array}{c}0.534 \\
(0.019)\end{array}$ & $\begin{array}{c}0.002 \\
(0.002)\end{array}$ & $\begin{array}{c}0.002 \\
(0.002)\end{array}$ \\
\hline Share married females & $\begin{array}{c}0.269 \\
(0.021)\end{array}$ & $\begin{array}{l}-0.002 \\
(0.002)\end{array}$ & $\begin{array}{l}-0.002 \\
(0.002)\end{array}$ \\
\hline Share widows & $\begin{array}{c}0.089 \\
(0.029)\end{array}$ & $\begin{array}{c}0.002 \\
(0.002)\end{array}$ & $\begin{array}{c}0.003 \\
(0.002)\end{array}$ \\
\hline Share married widows & $\begin{array}{c}0.272 \\
(0.021)\end{array}$ & $\begin{array}{l}-0.001 \\
(0.002)\end{array}$ & $\begin{array}{l}-0.001 \\
(0.002)\end{array}$ \\
\hline Share born in Province & $\begin{array}{c}0.640 \\
(0.036)\end{array}$ & $\begin{array}{c}0.0005 \\
(0.0032)\end{array}$ & $\begin{array}{c}0.001 \\
(0.004)\end{array}$ \\
\hline Share born abroad & $\begin{array}{c}0.033 \\
(0.008)\end{array}$ & $\begin{array}{l}0.001 \\
(0.001)\end{array}$ & $\begin{array}{c}0.001 \\
(0.001)\end{array}$ \\
\hline $\begin{array}{l}\text { Average number of voters } \\
\text { per building }\end{array}$ & $\begin{array}{c}703.7 \\
(106.4)\end{array}$ & $\begin{array}{c}3.53 \\
(7.20)\end{array}$ & $\begin{array}{c}4.23 \\
(8.65)\end{array}$ \\
\hline Share 2013 non-voters & $\begin{array}{c}0.132 \\
(0.026)\end{array}$ & $\begin{array}{c}0.006 \\
(0.004)\end{array}$ & $\begin{array}{c}0.007 \\
(0.005)\end{array}$ \\
\hline Share 2013 voters & $\begin{array}{c}0.809 \\
(0.032)\end{array}$ & $\begin{array}{l}-0.006 \\
(0.004)\end{array}$ & $\begin{array}{l}-0.007 \\
(0.005)\end{array}$ \\
\hline Share voters not in 2013 & $\begin{array}{c}0.059 \\
(0.014)\end{array}$ & $\begin{array}{c}0.0001 \\
(0.0010)\end{array}$ & $\begin{array}{c}0.0001 \\
(0.0012)\end{array}$ \\
\hline $\begin{array}{l}\text { F-test } \\
p \text {-value }\end{array}$ & & $\begin{array}{c}0.88 \\
0.553\end{array}$ & $\begin{array}{c}0.94 \\
0.496\end{array}$ \\
\hline Sample size & 760 & 760 & 228 \\
\hline
\end{tabular}

Notes: The sample in columns 1-2 (resp. 3) consists of the 20 civic list's candidates (resp. the 6 main candidates who were randomly assigned to canvass at least one precinct) times the 38 precincts included in the experiment. Column 1 reports means and standard deviations of row characteristics in control-group observations (precinctcandidates). Each cell in columns 2-3 reports estimates and precinct-clustered standard errors from regressions of a given precinct characteristic on a dummy for whether the candidate was randomly assigned to canvass a certain precinct. All regressions control for the random order used to assign precincts to canvassers.

** $\mathrm{p}<0.01, * \mathrm{p}<0.05, \sim \mathrm{p}<0.10$ 
Table A.6: Treatment Effects on Candidates' Votes Received: Main Candidates Only

\begin{tabular}{|c|c|c|c|c|c|c|c|c|c|}
\hline & \multicolumn{5}{|c|}{$\begin{array}{c}\text { Main Candidate } i \text { 's Votes } \\
\text { in Precinct } j\end{array}$} & \multicolumn{4}{|c|}{$\begin{array}{l}\text { Other Main Candidates' Votes } \\
\text { in Precinct } j\end{array}$} \\
\hline & $(1)$ & & $(2)$ & & (3) & (4) & $(5)$ & $(6)$ & \\
\hline & \multicolumn{9}{|c|}{ A. OLS } \\
\hline Candidate $i$ canvassed precinct $j$ & $\begin{array}{c}0.758 \\
(0.485)\end{array}$ & & $\begin{array}{c}0.998 \\
(0.535)\end{array}$ & $\sim$ & $\begin{array}{l}0.969 \sim \\
(0.563)\end{array}$ & $\begin{array}{l}-1.240 \\
(0.909)\end{array}$ & $\begin{array}{l}-0.651 \\
(0.513)\end{array}$ & $\begin{array}{l}-0.969 \\
(0.563)\end{array}$ & \\
\hline Candidate $i$ canvassed precinct $j$ & $\begin{array}{c}0.421 \\
(0.233)\end{array}$ & $\sim$ & $\begin{array}{c}0.738 \\
(0.279)\end{array}$ & ** & $\begin{array}{l}\text { B. Poi } \\
0.854 \\
(0.307)\end{array}$ & $\begin{array}{l}\frac{\text { on }}{-0.149} \\
(0.110)\end{array}$ & $\begin{array}{l}-0.106 \sim \\
(0.059)\end{array}$ & $\begin{array}{l}-0.145 \\
(0.064)\end{array}$ & \\
\hline Candidate $i$ canvassed precinct $j$ & $\begin{array}{c}0.749 \\
(0.301)\end{array}$ & $*$ & $\begin{array}{c}0.987 \\
(0.279)\end{array}$ & ** & $\begin{array}{c}\text { C. Negative } \\
1.024 \\
(0.307)\end{array}$ & $\begin{array}{c}\text { Binomial } \\
-0.164 \\
(0.110)\end{array}$ & $\begin{array}{l}-0.102 \sim \\
(0.055)\end{array}$ & $\begin{array}{l}-0.145 \\
(0.064)\end{array}$ & \\
\hline Candidate FEs & yes & & yes & & yes & yes & yes & yes & \\
\hline Precinct covariates & & & yes & & & & yes & & \\
\hline Precinct FEs & & & & & yes & & & yes & \\
\hline Mean dep. var. & 1.715 & & 1.715 & & 1.715 & 8.575 & 8.575 & 8.575 & \\
\hline Sample size & 228 & & 228 & & 228 & 228 & 228 & 228 & \\
\hline
\end{tabular}

Notes: The sample consists of the 6 main candidates of the civic list (i.e., candidates who were randomly assigned to canvass at least one precinct) times the 38 precincts included in the experiment. The treatment is a dummy for whether the candidate was randomly assigned to canvass a certain precinct. The dependent variable in columns 1-3 (4-6) is the number of preferences the main candidate herself/himself (all main candidates but oneself) received in the precinct. Standard errors are clustered at the precinct level.

$* * \mathrm{p}<0.01, * \mathrm{p}<0.05, \sim \mathrm{p}<0.10$ 
Table A.7: Minimum Detectable Effects on Candidates' Votes Received

\begin{tabular}{|c|c|c|c|c|c|c|}
\hline & \multicolumn{3}{|c|}{$\begin{array}{l}\text { Candidate } i \text { 's Votes } \\
\text { in Precinct } j\end{array}$} & \multicolumn{3}{|c|}{$\begin{array}{c}\text { Other Candidates' Votes } \\
\text { in Precinct } j\end{array}$} \\
\hline & $(1)$ & $(2)$ & $(3)$ & $(4)$ & $(5)$ & $(6)$ \\
\hline & \multicolumn{6}{|c|}{ A. OLS } \\
\hline \multirow[t]{2}{*}{ Candidate $i$ canvassed precinct $j$} & 1.378 & 1.410 & 1.418 & -4.678 & -2.009 & -1.398 \\
\hline & \multicolumn{6}{|c|}{ B. Poisson } \\
\hline \multirow[t]{2}{*}{ Candidate $i$ canvassed precinct $j$} & 0.662 & 0.784 & 0.910 & -0.341 & -0.146 & -0.112 \\
\hline & \multicolumn{6}{|c|}{ C. Negative Binomial } \\
\hline Candidate $i$ canvassed precinct $j$ & 0.918 & 0.970 & 1.030 & -0.344 & -0.150 & -0.112 \\
\hline
\end{tabular}

Notes: The table reports minimum detectable effects (MDEs) for each persuasion regression reported in Table 8.

To compute these MDEs, we first generate a grid of 1000 equally spaced points with range equal to a given Table 8's point estimate plus/minus 10 times the corresponding standard error. For each point on this grid, we take 9999 random draws from a normal distribution centered around this grid point with standard deviation equal to the original estimate's standard error and compute the share of draws that are significantly different from zero. For each regression in Table 8, our MDE is the grid point with the smallest absolute value having at least $80 \%$ random draws that are significantly different from zero. 
A.4 Toolkit (Translated from Italian) (For Online Publication) 


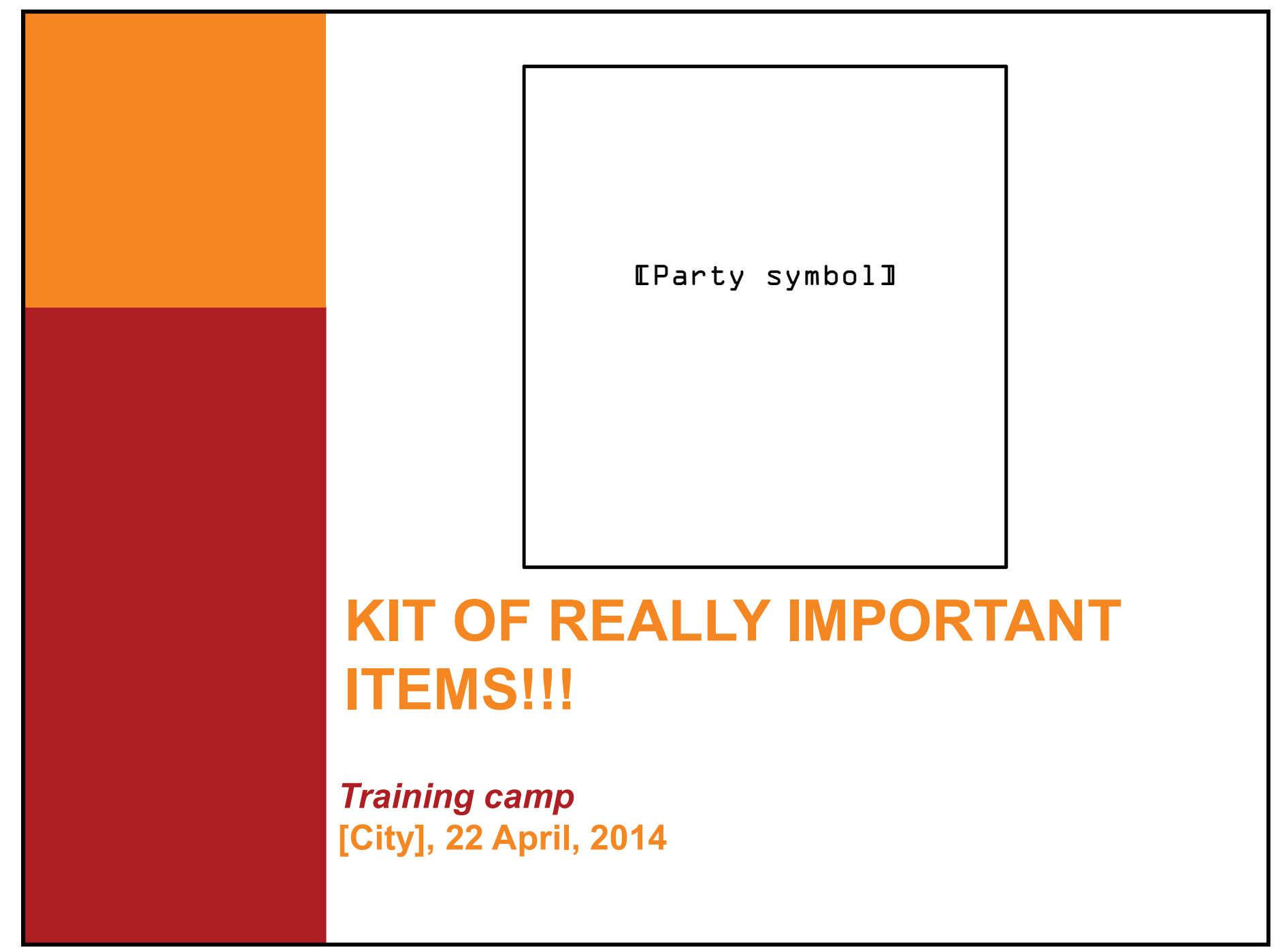




\section{Some examples of phrases useful door-to-door}

\section{Introducing yourself}

- "Good morning! My name's [Candidate's name], I'm a candidate for the City Council of [City] for the Civic List [List name]. [If you live nearby: "I live here, in Magellano Street"]. I'm here to talk about the coming elections on May 25th."

- I'm here because I think it's important to take part in these elections that are relevant both for Europe and the local community of [city] in such a difficult moment.

- Is your husband/wife at home too?

\section{Talking to your interlocutor - Identifying the kind of voter}

\section{- "Do you know our list?"}

- If not: "Until January I was town councilor for Urban Planning and Civil Protection. For example, I coordinated the extra works needed during the overflowing of the river [river's name], last September and the snow storm two years ago. Do you remember? Now l'm running with a Civil List made up of citizens like me and you."

- If yes: "What do you think of my work as councilor for Urban Planning and Civil Protection?"

- Try to understand if your interlocutor is right or left winged oriented : "What is your opinion about the work done by the outgoing Mayor [Mayor's name] and his team?"

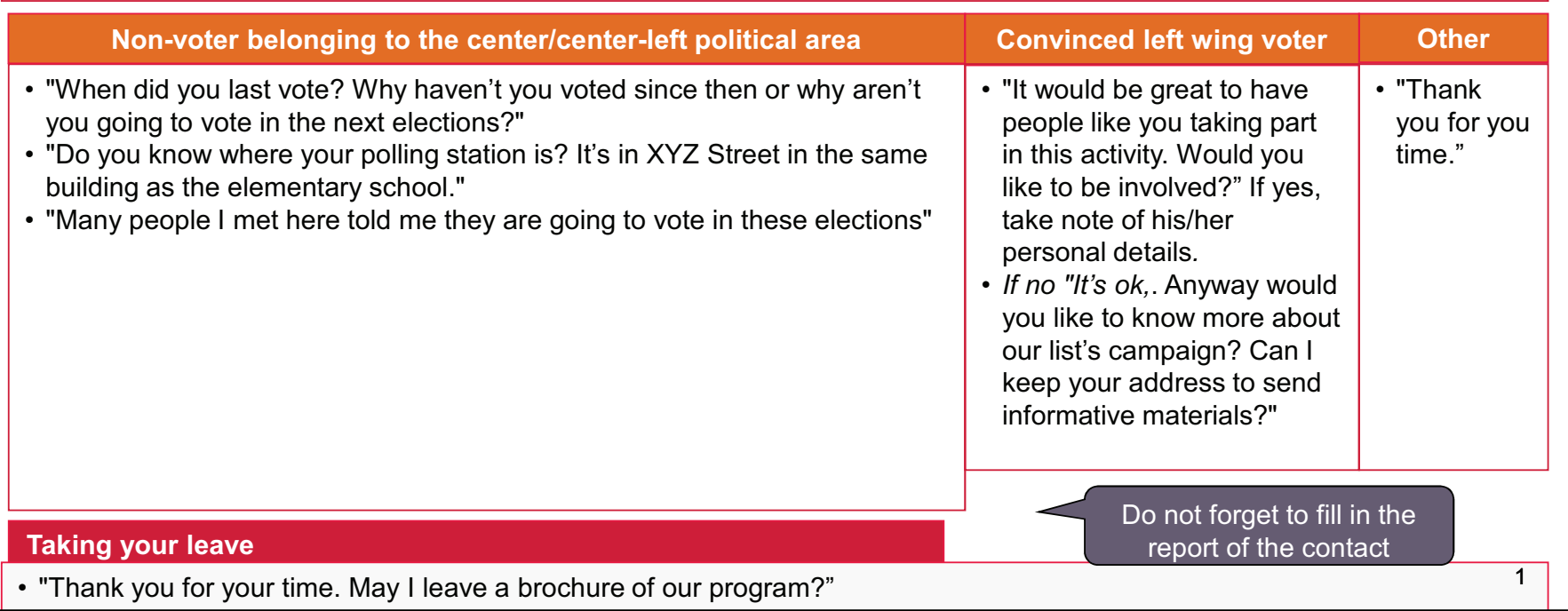




\section{Devising a convincing message}

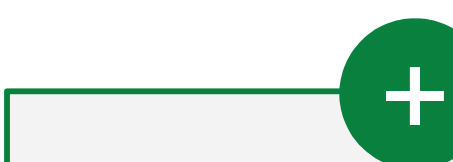

- Customize the message you want the citizens to share.

- Think of examples from your personal life to underline the importance of these elections and the impact that the city administration has on your life.

- LISTEN TO CITIZENS! Every citizen has different problems and opinions: the ideal message changes according to the people you interview.

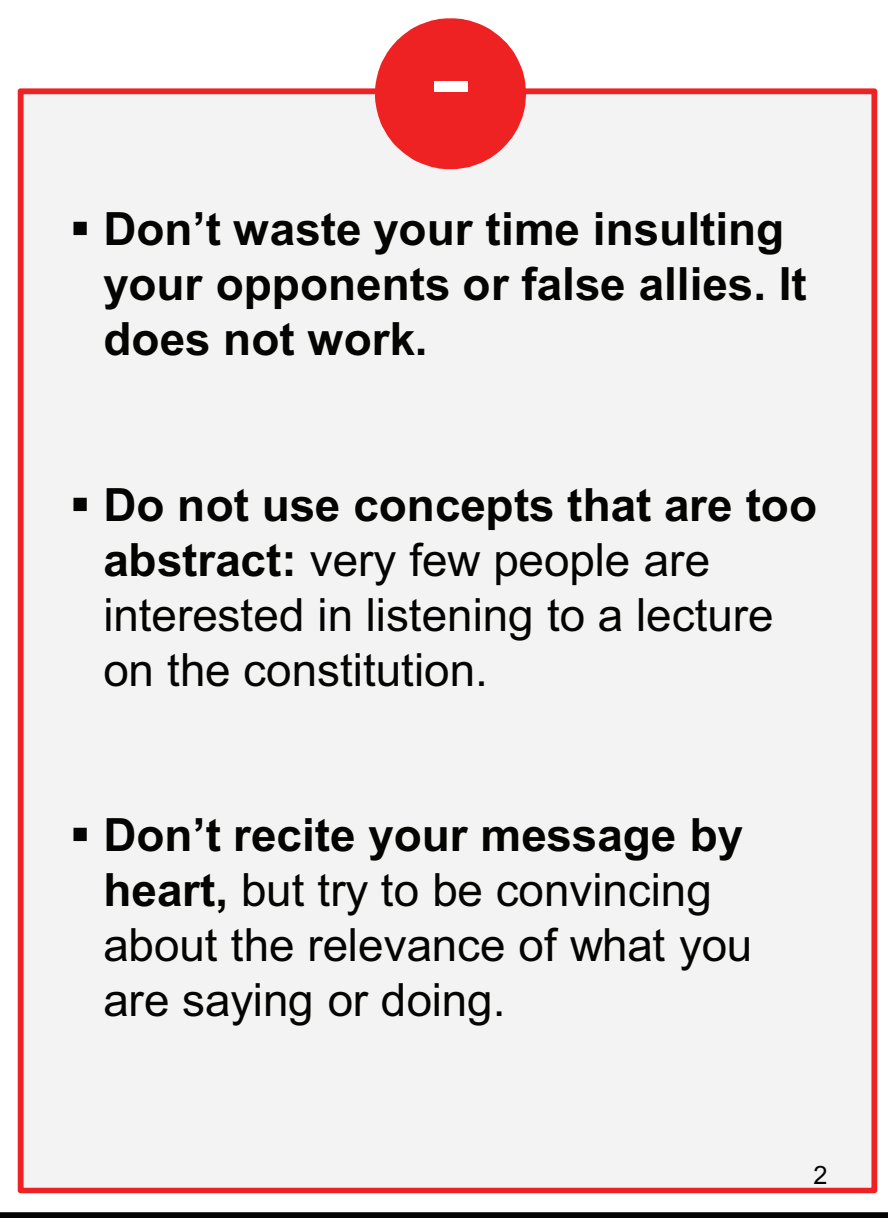




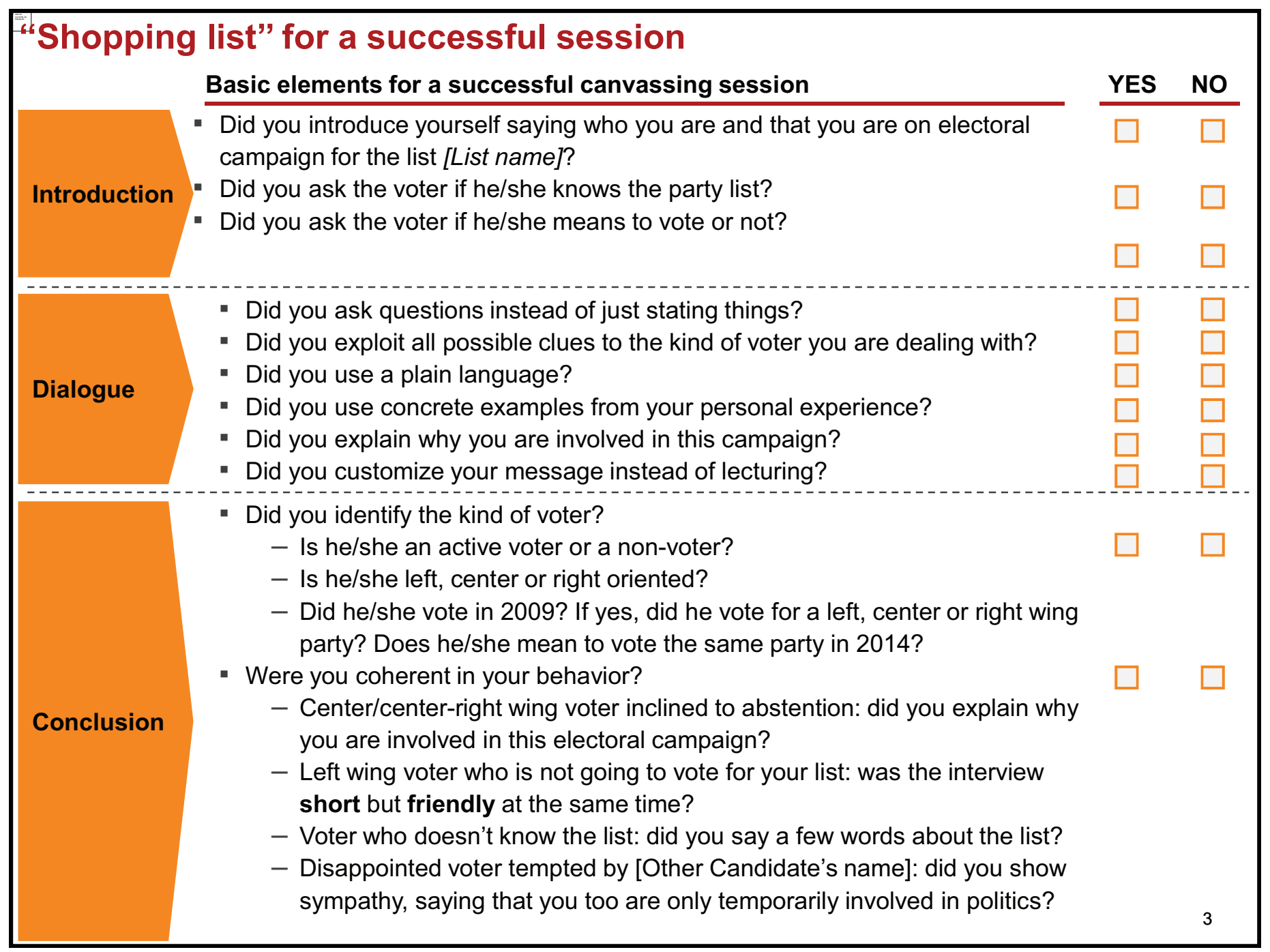




\section{Practical hints for a successful session}

\section{- Groups}

- Always two of you!

- You both interact with the voter

- You don't need higher education to be convincing

- Mixed pairs are advisable: man/woman, younger/older person etc.

- One member only in charge of filling in the report during the interview

\section{Interview timing}

- Less than two minutes if the voter is not in the "target group" (that is, possible center/center-left wing non-voter)!

- No more than five minutes in any other case

\section{When to go door-to-door}

- From Monday to Friday: from 6 to 8 p.m. (half an hour flexibility)

- Saturday: from 11 a.m. to 8 p.m.

\section{- Electoral material}

- T-shirts

- Leaflets. BE CAREFUL: keep them with you till the end of the conversation!

- Contact report 
A.5 Toolkit (Original Version) (For Online Publication) 


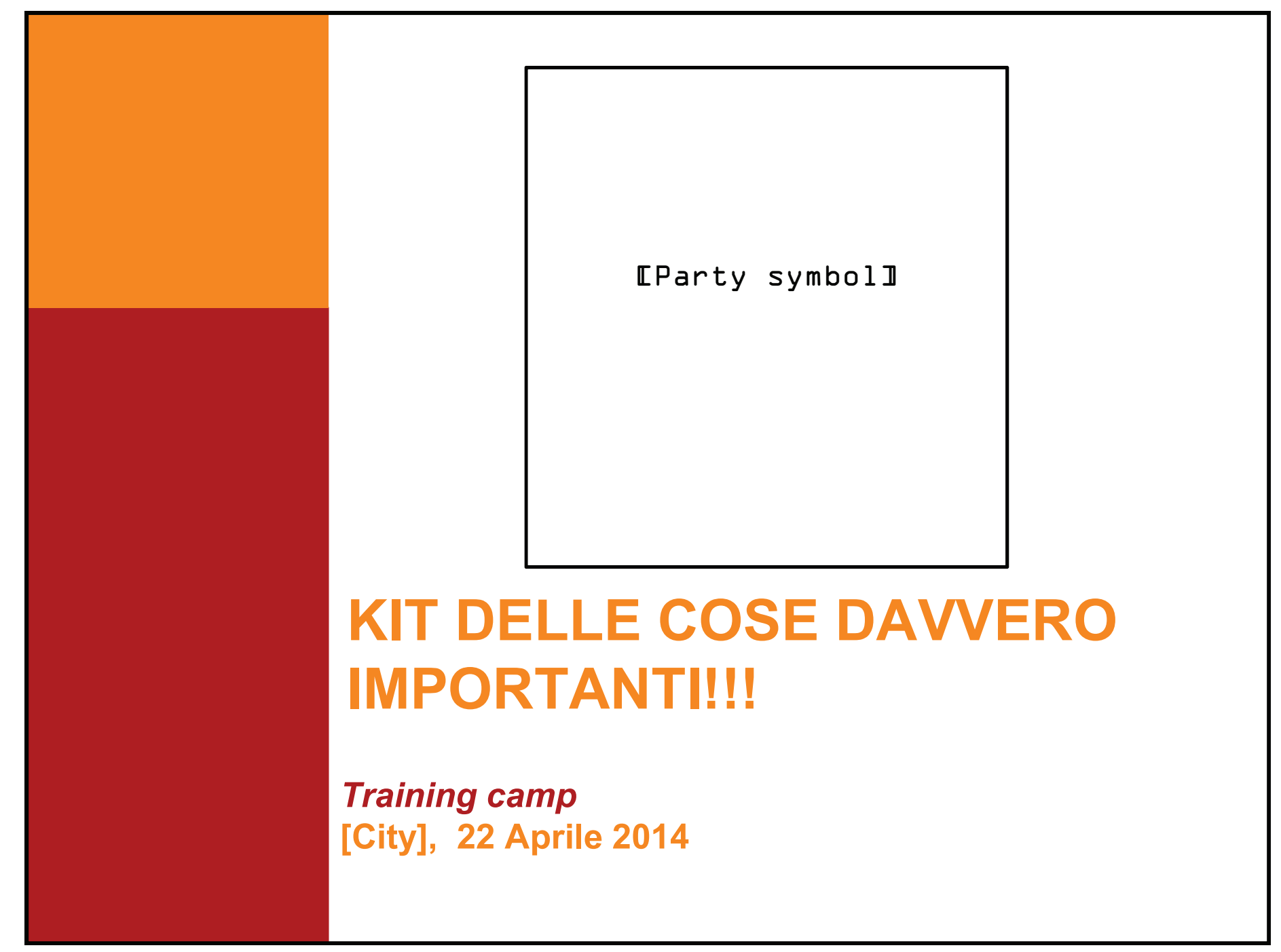




\section{Consigli per i volontari: qualche esempio di formule per il porta-a-porta}

\section{Presentarsi}

- «Buongiorno! Mi chiamo [Candidate's name], sono un candidato al Consiglio Comunale di [City] per la Lista Civica [List name]. [Se abitate nelle vicinanze: «Abito qui vicino, in Via Magellano »]. Sono venuto per parlare delle elezioni del 25 Maggio prossimo. 》

- Sono qui perche', in un momento cosi' difficile per l'Europa e per la citta', credo sia importante partecipare alle prossime elezioni, che saranno appunto sia europee sia comunali.

- C'e' per caso anche suo marito/moglie in casa?

\section{Dialogare con il vostro interlocutore - identificare il tipo di elettore}

- «Conosce [Candidate's name] o la nostra Lista? »

- Se no: "Fino a gennaio, [Candidate's name] era assessore ai Lavori Pubblici e alla Protezione Civile. Si e’ per esempio occupato di coordinare i lavori straordinari durante l'esondazione del [river's name] dello scorso settembre e della bufera di neve di due anni fa. Ricorda? Ora e' capolista di una Lista Civica fatta di cittadini come lei e come noi due.»

- Se si: «Cosa ne pensa del suo operato come Assessore ai Lavori Pubblici e Protezione Civile?»

- Prova a capire se il tuo interlocutore e' di destra o di sinistra : " Cosa ne pensa dell'operato del Sindaco uscente [Mayor's name] e della sua giunta? »

\begin{tabular}{|c|c|c|}
\hline Astensionista di centro/centro-sinistra & Elettore attivo di sinistraz & Altro \\
\hline $\begin{array}{l}\text { - "Quand'e' andato a votare l'ultima volta? Come mai non ha piu' votato da } \\
\text { allora o non e' intenzionato a votare alle prossime elezioni? » } \\
\text { - "Sa dov'e' il suo seggio? E' in Via XYZ, nella scuola elementare » } \\
\text { " Molte persone che ho incontrato qui hanno detto che andranno a votare a } \\
\text { queste elezioni » }\end{array}$ & $\begin{array}{l}\text { - «Sarebbe davvero } \\
\text { importante avere persone } \\
\text { come lei ad aiutarci in } \\
\text { questa attivita' . Le } \\
\text { piacerebbe partecipare? » } \\
\text { Se si, prendere i contatti. } \\
\text { - Se no « Va bene lo stesso. } \\
\text { Sarebbe interessata a } \\
\text { sapere di piu' della } \\
\text { campagna di Paolo Nanni? } \\
\text { Accetterebbe di lasciarmi il } \\
\text { suo indirizzo per ricevere } \\
\text { del materiale informativo? » }\end{array}$ & $\begin{array}{l}\text { - «Grazie lo } \\
\text { stesso per il } \\
\text { suo tempo» }\end{array}$ \\
\hline & & \\
\hline
\end{tabular}




\section{Costruire un messaggio convincente}

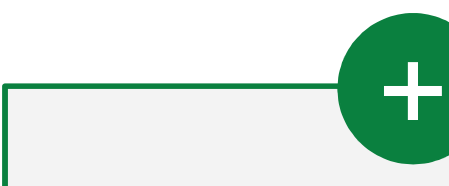

- Personalizzate il messaggio che volete condividere con i cittadini

- Pensate a esempi della vostra vita personale per sottolineare l'importanza di queste elezioni e dell'impatto che l'amministrazione comunale ha sulla vostra vita

- ASCOLTATE I CITTADINI! Ogni cittadino ha problemi e opinioni diverse: il messaggio ideale varia da persona a persona

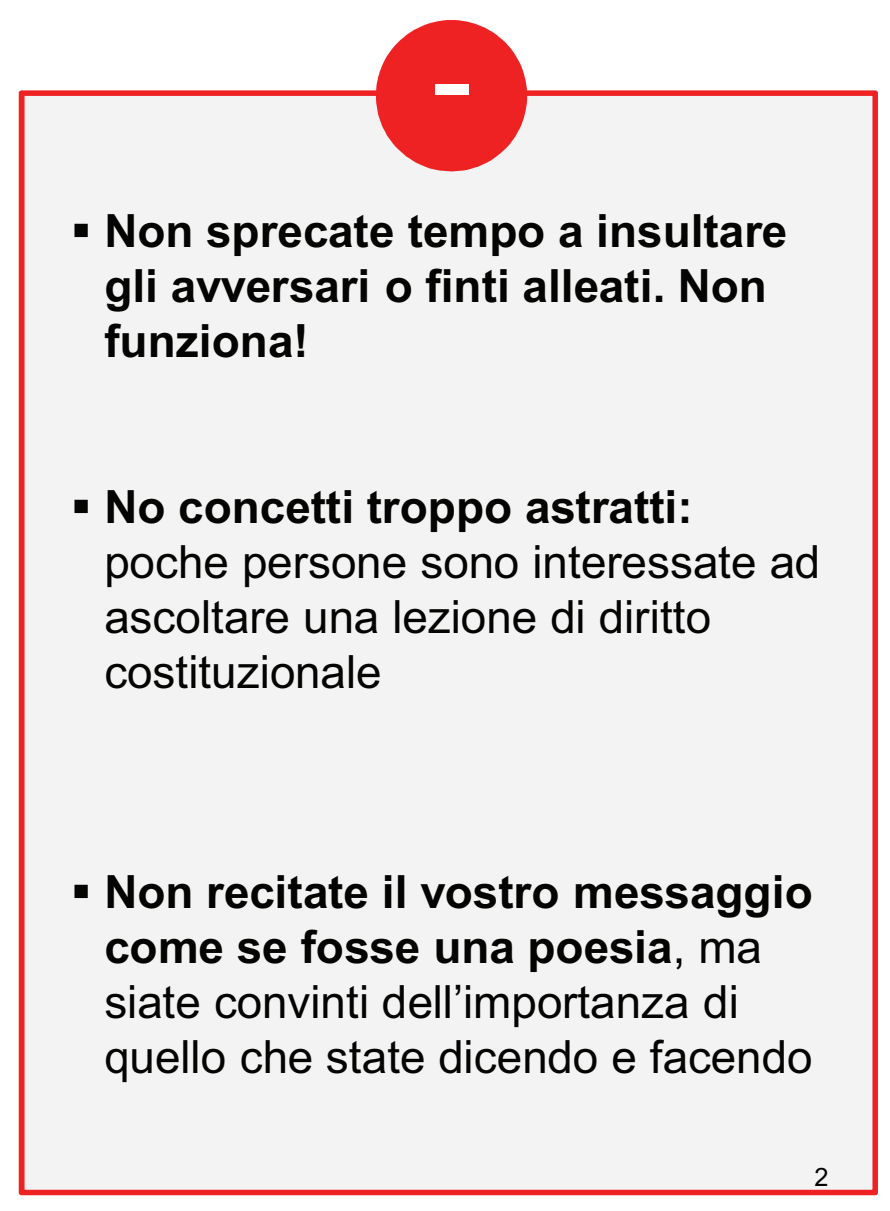




\begin{tabular}{|c|c|c|c|}
\hline \multicolumn{4}{|c|}{ “Lista della spesa” per una sessione di successo } \\
\hline $\begin{array}{l}\text { Introduzi } \\
\text { one }\end{array}$ & $\begin{array}{l}\text { - Ti sei presentato dicendo chi sei e che stai facendo campagna elettorale per la } \\
\text { lista [List name]? } \\
\text { - Hai chiesto se l'elettore conosce la lista? } \\
\text { - Hai chiesto se l'elettore pensa di andare a votare o di astenersi? }\end{array}$ & $\square$ & $\square$ \\
\hline Dialogo & $\begin{array}{l}\text { - Hai fatto domande anziche' parlare sempre da solo? } \\
\text { - Hai sfruttato ogni possibile indizio sul tipo di elettore che avevi davanti? } \\
\text { - Hai usato parole semplici? } \\
\text { - Hai usato esempi concreti tratti dalla tua esperienza personale? } \\
\text { - Hai detto che cosa ti ha spinto a partecipare a questa campagna elettorale? } \\
\text { - Hai personalizzato il messaggio invece di fare una lezione? }\end{array}$ & $\begin{array}{l}\square \\
\square \\
\square \\
\square \\
\square\end{array}$ & $\begin{array}{l}\square \\
\square \\
\square \\
\square \\
\square\end{array}$ \\
\hline $\begin{array}{l}\text { Conclusi } \\
\text { one }\end{array}$ & $\begin{array}{l}\text { Hai identificato il tipo di elettore? } \\
\text { - E' un elettore attivo o un astensionista? } \\
\text { - E' di sinistra, centro, o destra? } \\
\text { - Ha votato nel } 2009 \text { ? Se si', ha votato per un partito di sinistra, centro o destra? } \\
\text { Pensa di votare lo stesso partito nel } 2014 \text { ? } \\
\text { Hai adottato un atteggiamento coerente? } \\
\text { - Elettore di centro/centro-destra tentato dall'astensione: hai spiegato perche' } \\
\text { partecipi alla campagna elettorale? } \\
\text { - Elettore di sinistra che non votera' mai per la tua Lista: hai mantenuto la } \\
\text { conversazione breve ma comunque cordiale? } \\
\text { - Elettore che non conosce la lista: hai speso qualche parola sulla Lista? } \\
\text { - Elettore deluso dalla politica e tentato da [Other Candidate's name]: hai mostrato } \\
\quad \text { empatia e hai detto che anche tu sei un cittadino in prestito alla politica? }\end{array}$ & $\square$ & $\square$ \\
\hline
\end{tabular}




\section{Suggerimenti pratici per una sessione di successo}

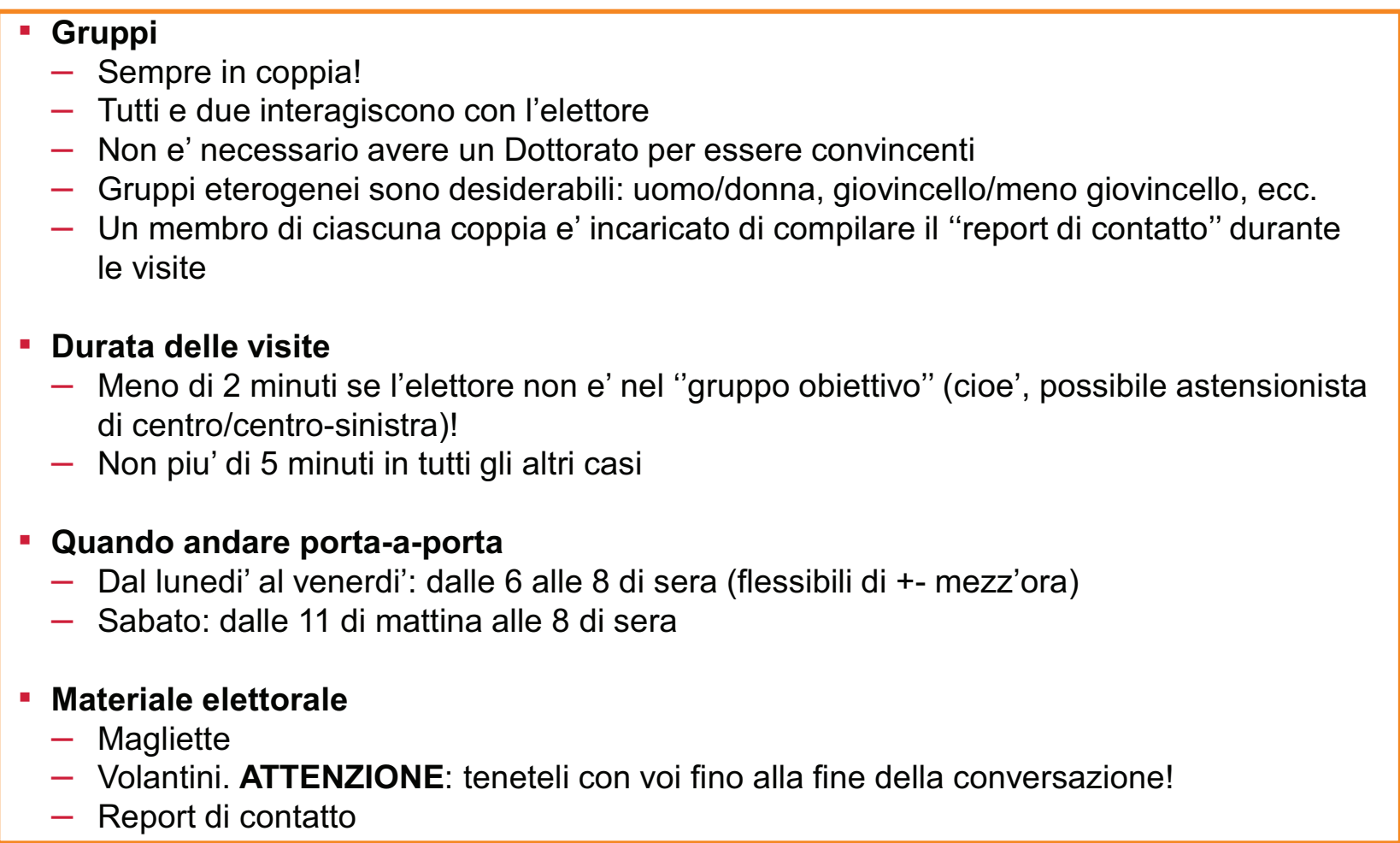


A.6 Leaflet (Translated from Italian) (For Online Publication)

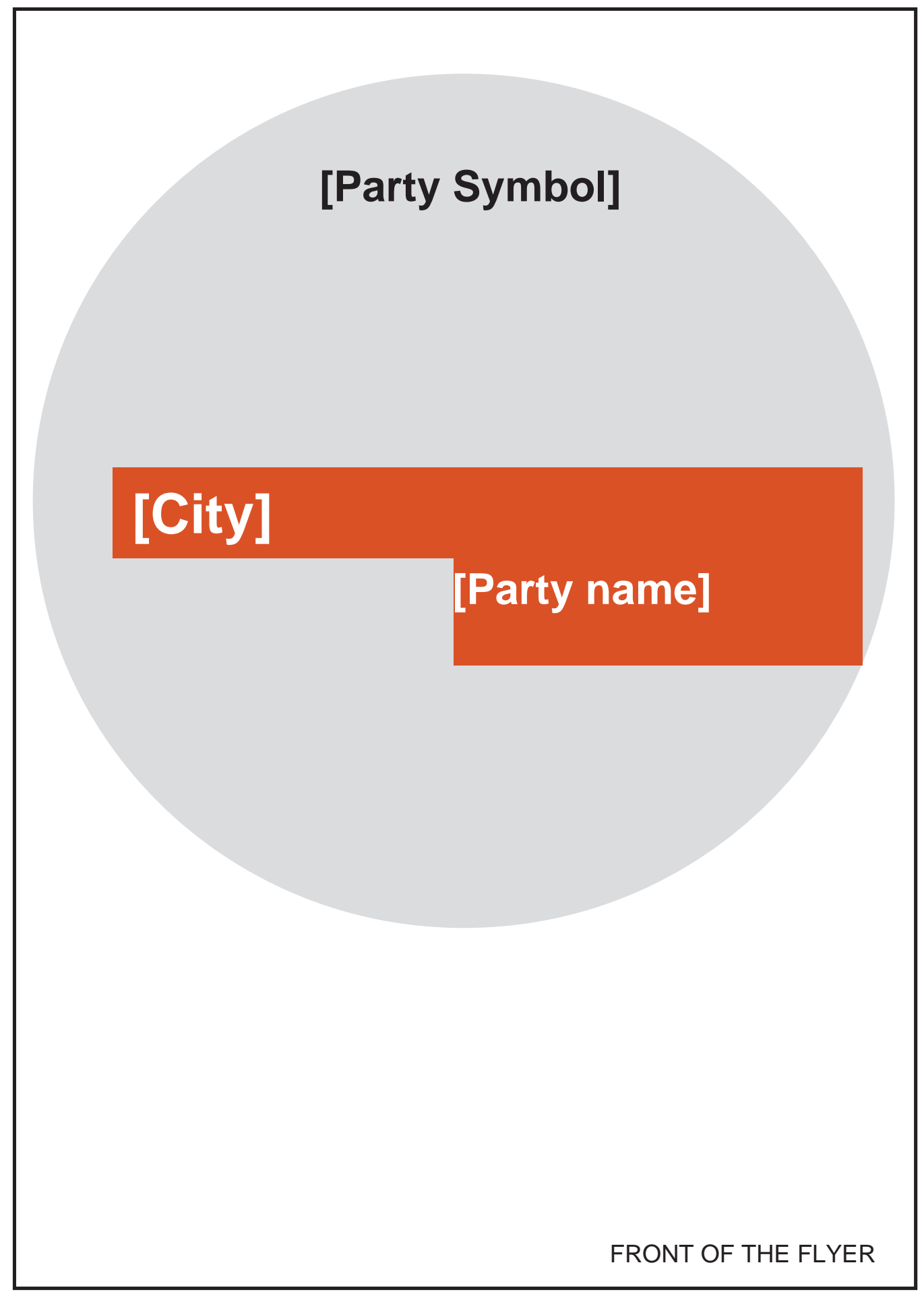


In our complex society, hardly accustomed to facing complexity, the best possible town administration must start from the present, from what we have. The way to do this is through the promotion of people from every walk and stage of life.

\section{"At work, I look after you" \\ WORK}

Work is a basic, natural human occupation. We must reward the work of individual workers, small businesses, commercial and service-based firms. Our activities are based on reciprocity. We aim to promote free and noble examples of solidarity by offering services to one another. If the community needs a service, there must be someone, appointed by the administration, ready to provide it in exchange for another professional service. Every citizen should take on the responsibility to look after other members of the community as if they were an extended family. The best possible administration strives to spread this spirit of friendship among its constituents and measures its performance using the index of public happiness.

\section{"On the street, I look after you" \\ MAINTENANCE AND URBAN PLAN}

We must take good care of shared spaces and public land to make our town friendly to everyone - pedestrians, children, seniors and the disabled. Schools, roads, parks and public lightings need continuous attention and maintenance. We must commit to realizing the plan for railroad underpasses. We must upgrade existing buildings, expand and reform public housing to create new rent-controlled units, and explore new ways of sharing the community space.

\section{"On dark nights, I look after you" SAFETY}

We must make sure that even at night our town is safe for women, old people, the disabled and teenagers. We must make targeted investments in the development and coordination of civil protection.

\section{"I don't sleep and look after you" \\ HEALTH AND ENVIRONMENT}

We view good health as well-being in every field and stage of life. Sufficient and suitable waste recycling according to citizens' needs. We must give attention and good care to our parks, as they are the property of all citizens.

\section{"As you find yourself, I look after you" SCHOOL}

Let's take culture back to our schools and restore their dignity as the quintessential educational space. Schools must be open to every age and feed every human art and talent. Students, schools, administrators must be in constant dialogue to exchange views and together fight against drugs, gambling, and eating disorders that are real threats to our girls and boys. 
A.7 Leaflet (Original Version) (For Online Publication)

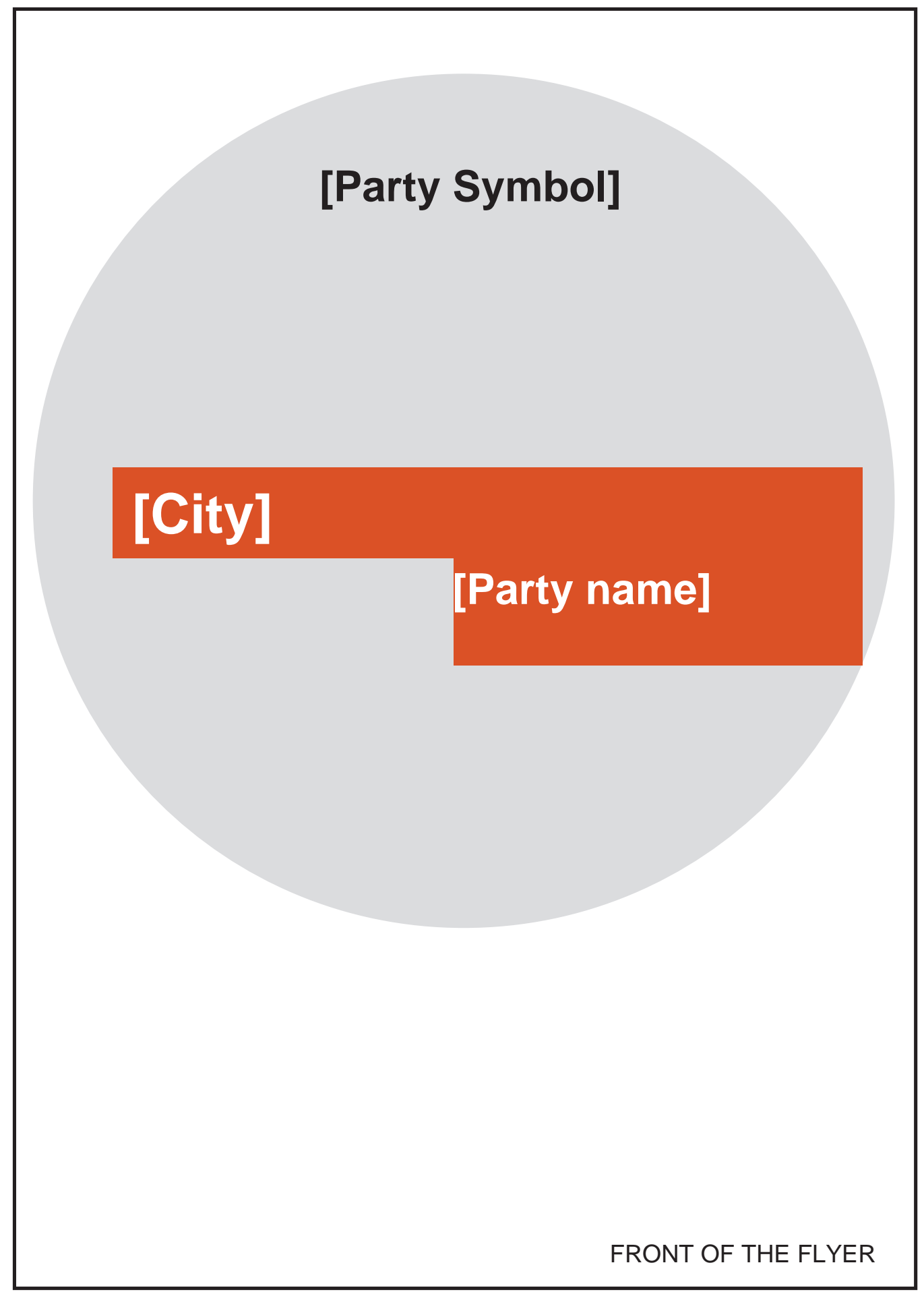


In una società così complessa e poco abituata ad affrontare la complessità, la migliore Amministrazione possibile di una città deve assolutamente partire dal presente, da quello che si ha. L'opportunità scaturisce dalla valorizzazione delle persane in agni ambito ed età della vita.

\section{"lo lavoro e penso a te"}

LAVORO

II lavoro inteso come disposizione naturale dell'uomo. Massima valorizzazione delle piccole e piccolissime imprese artigianali, commerciali e di servizi. Attività basate sui criterio di reciprocità. Si tratta di promuovere esempi virtuosi di solidarietà, gratuiti, in cui si dona reciprocamente qualche servizio. Se la comunità ha bisogno di qualche servizio ci deve essere qualcuno, individuato dall'Amministrazione, pronto a svolgerlo in cambio magari di un'altra prestazione professionale. Ogni cittadino si assume le responsabilità della cura della comunità come in una famiglia molto allargata.

La migliore Amministrazione possibile, si prodiga per diffondere e mantenere vivo questo spirito di amicizia tra i cittadini basando il suo operato sull'Indice di Felicità Pubblica.

\section{"lo cammino e penso a te" MANUTENZIONE E PIANO URBANISTICO}

Massima cura del suolo pubblico e del territorio, per una città a misura di pedoni, bambini, anziani, disabili. Scuole, strade, parchi e pubblica illuminazione esigono manutenzione e controlli continui. Impegno ad attuare il piano di interramento della ferrovia. Riqualificazione dell'edilizia esistente ed ampliamento dell'edilizia sociale destinata all'affitto e a nuove forme di coabitazione.

\section{"Sono al buio e penso a te" SICUREZZA}

Massima attenzione alla città anche nelle ore notturne perché sia a misura di donne, anziani, disabili e adolescenti. Presidio del territorio da parte della Polizia Municipale h24. Specifici investimenti sullo sviluppo ed il coordinamento della Protezione Civile.

"lo non dormo e penso a te"

SALUTE E AMBIENTE

Salute intesa come ben-essere in ogni ambito ed età della vita. Una raccolta differenziata a misura delle esigenze di tutti gli abitanti. Attenzione e cura particolare dei nostri parchi, considerati come luoghi dei cittadini.

\section{"lo mi cerco e penso a te"} SCUOLA

Riportiamo la cultura nelle scuole e restituiamo alle stesse la dignità di spazio educativo per eccellenza. Scuole aperte a tutte le età e a tutte le arti umane, una scuola adatta ad aiutare chi la frequenta a capire quello che è. Studenti, istituzioni scolastiche, amministratori devono mantenersi in dialogo in modo da garantire spazi comuni di confronto per combattere quei fenomeni, come la droga, il gioco d'azzardo, le malattie da disturbi alimentari, che sono vere e proprie piaghe per l'età adolescenziale. 